\title{
Variation of Hydrometeorological Conditions along a Topographic Transect in Northwestern Mexico during the North American Monsoon
}

\author{
Enrique R. Vivoni, Hugo A. Gutiérrez-Jurado, Carlos A. Aragón, luis A. Méndez-Barroso, \\ Alex J. Rinehart, And Robert L. WyckofF \\ Department of Earth and Environmental Science, New Mexico Institute of Mining and Technology, Socorro, New Mexico
}

JULIO C. RODRÍGUEZ

Instituto del Medio Ambiente y Desarrollo Sustentable del Estado de Sonora, Hermosillo, Sonora, Mexico

CHRISTOPHER J. WATTS

Departamento de Física, Universidad de Sonora, Hermosillo, Sonora, Mexico

John D. Bolten and Venkataraman LAKshmi

Department of Geological Sciences, University of South Carolina, Columbia, South Carolina

THOMAS J. JACKSON

USDA/ARS/Hydrology and Remote Sensing Laboratory, Beltsville, Maryland

(Manuscript received 2 December 2005, in final form 6 March 2006)

\begin{abstract}
Relatively little is currently known about the spatiotemporal variability of land surface conditions during the North American monsoon, in particular for regions of complex topography. As a result, the role played by land-atmosphere interactions in generating convective rainfall over steep terrain and sustaining monsoon conditions is still poorly understood. In this study, the variation of hydrometeorological conditions along a large-scale topographic transect in northwestern Mexico is described. The transect field experiment consisted of daily sampling at 30 sites selected to represent variations in elevation and ecosystem distribution. Simultaneous soil and atmospheric variables were measured during a 2-week period in early August 2004. Transect observations were supplemented by a network of continuous sampling sites used to analyze the regional hydrometeorological conditions prior to and during the field experiment. Results reveal the strong control exerted by topography on the spatial and temporal variability in soil moisture, with distinct landscape regions experiencing different hydrologic regimes. Reduced variations at the plot and transect scale during a drydown period indicate that homogenization of hydrologic conditions occurred over the landscape. Furthermore, atmospheric variables are clearly linked to surface conditions, indicating that heating and moistening of the boundary layer closely follow spatial and temporal changes in hydrologic properties. Land-atmosphere interactions at the basin scale $\left(\sim 100 \mathrm{~km}^{2}\right)$, obtained via a technique accounting for topographic variability, further reveal the role played by the land surface in sustaining high atmospheric moisture conditions, with implications toward rainfall generation during the North American monsoon.
\end{abstract}

\section{Introduction}

The North American monsoon (NAM) is the primary climate phenomenon controlling summer precipi-

Corresponding author address: Enrique R. Vivoni, Dept. of Earth and Environmental Science, New Mexico Institute of Mining and Technology, MSEC 244, 801 Leroy Place, Socorro, NM 87801.

E-mail: vivoni@nmt.edu

DOI: $10.1175 / J C L I 4094.1$

(C) 2007 American Meteorological Society tation in northwestern Mexico and the southwestern United States (e.g., Douglas et al. 1993; Adams and Comrie 1997). Convective storms during the monsoon period can account for a large percentage of the total annual precipitation in the region (Sheppard et al. 2002) and lead to significant impacts on the local climate, ecosystem function, and water resources (Higgins et al. 2003). Despite its regional impact, relatively little is currently known about the potential interactions between the monsoon system and land surface properties 
(e.g., topography, soil moisture, vegetation) that may play a role in initiating and sustaining moist convection. The land and atmosphere interaction may be particularly important for topographically complex areas in the monsoon region. For example, Gochis et al. (2004) showed important terrain controls on the distribution of precipitation using rain gauge observations along topographic transects in the Sierra Madre Occidental (SMO). In particular, the authors found that at high elevations, summer precipitation was more frequent ( $\sim 1-2$ days), but of lower intensity, as compared to observations at lower elevations, suggesting that topography controls the diurnal cycle of convection.

While terrain factors have been observed to influence monsoon rainfall (e.g., Brown and Comrie 2002; Gochis et al. 2004), the dynamic nature of land surface properties, in particular soil moisture and vegetation, have received much less attention. Theoretically, soil wetness and plant cover can influence the surface energy balance through changes to the albedo, temperature, and partitioning into sensible and latent heat fluxes. Eltahir (1998) hypothesized that variations in surface conditions caused by soil moisture and vegetation dynamics can have a direct impact on the moist static energy in the boundary layer with subsequent effects on rainfall generation. Two measurable features of the feedback mechanism are that an increase in soil moisture leads to a decrease in surface temperature and an increase in water vapor in the lower atmosphere. A soil moisture-vegetation-rainfall feedback mechanism has been subsequently investigated in the North American monsoon system through modeling studies (e.g., Small 2001; Xu et al. 2004b; Matsui et al. 2005). Nevertheless, the observations necessary to understand the interaction of atmospheric conditions with the land surface, in particular over complex terrain in northwestern Mexico, have not been collected in a systematic fashion. Furthermore, the linkage between the land surface and the monsoon system is possibly enhanced by the seasonal greening and high transpiration of a subtropical ecosystem arranged along specific elevation bands in the region (e.g., Salinas-Zavala et al. 2002; Higgins et al. 2003). The deciduous subtropical scrubland may have an important control, through its changes in albedo and evaporative fraction, on the recycling of moisture back to the atmosphere, with subsequent impacts on rainfall generation.

In this study, we describe the spatial and temporal variabilities in the hydrometeorological conditions observed along a steep, topographic transect in northwestern Mexico during the North American monsoon. Our study is based on a consistent set of daily field observations across a local domain ( $\sim 22 \mathrm{~km}$ transect) over a 2-week period in August 2004. More importantly, the field study was designed to assess the topographic controls on soil moisture, soil temperature, and loweratmospheric conditions, which are poorly known but critical for understanding the North American monsoon. The field campaign formed part of an intensive observation period carried out under the auspices of the Soil Moisture Experiment 2004 (SMEX04) and the North American Monsoon Experiment (NAME). A common objective of the experiments has been to improve the understanding of the monsoon and its relation with the continental landmass and its hydrologic properties (NAME Science Team 2004; SMEX Science Team 2004). Here, we address the observed interactions between atmospheric conditions and the land surface properties along an elevation transect selected across a range of terrain and vegetation conditions representative of the complex region. While the field campaign was limited in its spatial and temporal extent, we believe that the atmospheric and hydrologic observations and their interpretation are valuable for improving our understanding of the linkage between monsoon precipitation and land surface properties.

The study is organized as follows. Section 2 presents a description of the study site and its characteristics, as well as the sampling methods employed during the field campaign. In section 3 , we present the study results, focusing on the spatial and temporal variability of the atmospheric forcing and hydrologic response at the regional and transect scale. This section also explores the topographic controls on soil moisture distribution and linkages observed between atmospheric and land surface conditions. Of particular importance is an attempt to derive the temporal variability of atmospheric humidity and soil moisture averaged over the scale of a watershed. Based on basin-averaged conditions, we assess the significance of land-atmosphere interactions during the observation period. In section 4, we discuss the study results, provide conclusions, and recommend fruitful avenues for future work.

\section{Observations and sampling methods}

In the following, we describe the study site, data collection, instrumentation, and analysis used to investigate the hydrometeorological conditions along the topographic transect. The field experiment was designed to assess the influence of land surface properties on the variability of monsoon precipitation and its hydrologic response. Our experimental plan is based on similar soil moisture field campaigns conducted over large regions for validating remote sensing data (e.g., Schmugge et al. 1994; Jackson and Hsu 2001; Cosh et al. 2004). We 


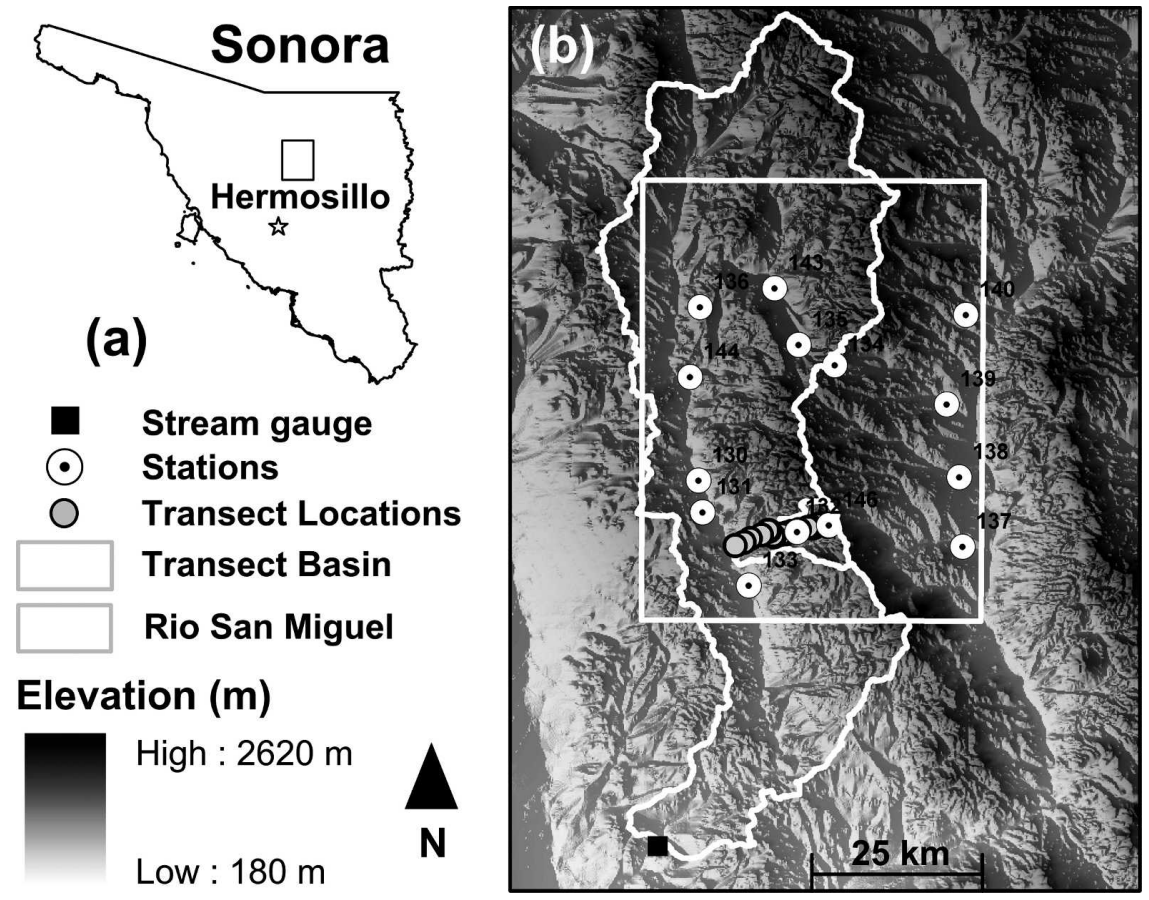

FIG. 1. Study site. (a) Region location $(75 \mathrm{~km} \times 50 \mathrm{~km}$ box) in northern Sonora, Mexico, with approximate distance to the capital Hermosillo. (b) Topographic transect locations and watershed $\left(\sim 100 \mathrm{~km}^{2}\right)$ in the Río San Miguel basin $\left(\sim 3796 \mathrm{~km}^{2}\right)$. Note the location of the regional sampling sites, with rainfall and soil moisture sensors, and the stream discharge observation point. The topographic map, derived from a 90-m DEM (INEGI 1998), depicts the north-south-trending mountain ranges and river valleys of the Río San Miguel (left) and Río Sonora (right).

adapted the sampling strategy to obtain the spatial and temporal variability of atmospheric and land surface conditions over the elevation gradient. The transect study was complemented by data collection from a regional network of continuous, ground-based sensors, satellite imagery, and aircraft observations of rainfall, soil moisture, and vegetation variability, among others (SMEX Science Team 2004).

\section{a. Study site}

The study site is located in northern Sonora, Mexico, within a rural region characterized by complex topography, ephemeral rivers, and seasonally green vegetation. The mean annual rainfall in the region ranges from 400 to $500 \mathrm{~mm}$, with $50 \%-70 \%$ occurring during the monsoon (CNA 2002). Figure 1 depicts the location of the study region, a $75 \mathrm{~km} \times 50 \mathrm{~km}$ box, selected based upon its topographic variability as represented by a 90-m digital elevation model (DEM) (INEGI 1998). Note the north-south-trending mountain ranges and river valleys in the domain, which forms part of the Sierra Madre Occidental. The topographic distribution is characterized by a high mean elevation and a large elevation range, which are primarily due to the effects of channel incision (Coblentz and Riitters 2004). Two major ephemeral rivers flow north-south through the region: Río San Miguel (west) and Río Sonora (east), with the former draining into the latter south of the domain. A discharge observation point at El Cajón was used to delineate the Río San Miguel watershed ( 3796 $\mathrm{km}^{2}$ ) from the 90-m DEM. Also depicted in Fig. $1 \mathrm{~b}$ are the locations of the regional sampling sites, each equipped with a rain gauge and soil moisture sensor, and the location of transect sites visited during the field campaign (see section $2 b$ ).

Figure 2a depicts the ecosystem distribution in the vicinity of a small tributary to the Río San Miguel $\left(\sim 100 \mathrm{~km}^{2}\right)$, which encompasses the majority of the transect sites (Table 1, labeled 1 to 30 from high to low elevation). The watershed is composed of an ephemeral stream flowing west from Sierra Aconchi to the major river valley, close to the town of Opodepe, in the state of Sonora. Note the rural road that traverses the watershed and climbs nearly $700 \mathrm{~m}$ over a distance of $\sim 22$ $\mathrm{km}$. Along the transect, plant communities vary considerably and include desert scrub, mesquite forest, sub- 

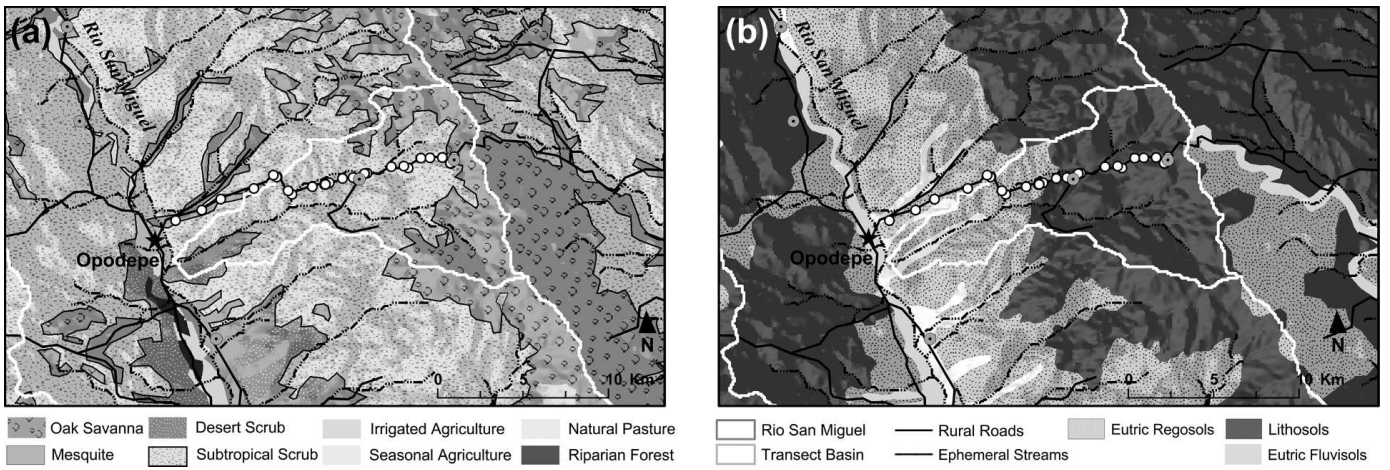

FIG. 2. Vegetation and soil cover characteristics of study transect and tributary to the Río San Miguel, near Opodepe, Sonora. (a) Spatial distribution of plant communities (SIUE-IMADES 1998). Note that the plant types along the transect are (in order from high to low elevation) oak savanna, subtropical scrub, mesquite forest, and desert scrub. (b) Spatial distribution of major soil classes (INIFAP 2001). Note that the soil types in the transect are (in order from high to low elevation) lithosols, eutric regosols, and eutric fluvisols. The rural road network and ephemeral streams (derived from analysis of the 90-m DEM) are also illustrated.

TABLE 1. Characteristics of transect sites. Geographic location and elevation obtained from averaging four GPS measurements at each site [North American Datum of 1983 (NAD83); spheroid Geodetic Reference System 1980 (GRS1980)]. The transect sites are labeled with IDs ranging from 1 to 30, ordered along the transect from the mountaintop to the lower valley bottom. Note that transition zones exist between ecosystems so that boundaries between vegetation types may not be sharp along the transect.

\begin{tabular}{ccccl}
\hline \hline $\begin{array}{c}\text { Transect } \\
\text { site ID }\end{array}$ & Lat $\left({ }^{\circ} \mathrm{N}\right)$ & Lon $\left({ }^{\circ} \mathrm{W}\right)$ & $\begin{array}{c}\text { Elev } \\
(\mathrm{m})\end{array}$ & \multicolumn{1}{c}{$\begin{array}{c}\text { Vegetation } \\
\text { type }\end{array}$} \\
\hline 1 & 29.9721733 & -110.4703828 & 1371 & Oak savanna \\
2 & 29.9701381 & -110.4714819 & 1331 & Oak savanna \\
3 & 29.9685256 & -110.4722264 & 1304 & Oak savanna \\
4 & 29.9686619 & -110.4724225 & 1293 & Oak savanna \\
5 & 29.9718103 & -110.4766450 & 1243 & Oak savanna \\
6 & 29.9715472 & -110.4831661 & 1198 & Subtropical scrub \\
7 & 29.9714394 & -110.4879553 & 1122 & Subtropical scrub \\
8 & 29.9662939 & -110.4945422 & 1098 & Subtropical scrub \\
9 & 29.9672233 & -110.4969111 & 1068 & Subtropical scrub \\
10 & 29.9668967 & -110.5035253 & 956 & Subtropical scrub \\
11 & 29.9635417 & -110.5162794 & 926 & Subtropical scrub \\
12 & 29.9633386 & -110.5175242 & 916 & Subtropical scrub \\
13 & 29.9604033 & -110.5218703 & 898 & Subtropical scrub \\
14 & 29.9612667 & -110.5235036 & 868 & Mesquite forest \\
15 & 29.9608175 & -110.5291231 & 845 & Mesquite forest \\
16 & 29.9583517 & -110.5361300 & 825 & Mesquite forest \\
17 & 29.9575658 & -110.5385069 & 821 & Mesquite forest \\
18 & 29.9574839 & -110.5383106 & 821 & Mesquite forest \\
19 & 29.9575469 & -110.5382894 & 825 & Mesquite forest \\
20 & 29.9577356 & -110.5380086 & 826 & Mesquite forest \\
21 & 29.9565142 & -110.5449475 & 802 & Mesquite forest \\
22 & 29.9524442 & -110.5556089 & 778 & Subtropical scrub \\
23 & 29.9543283 & -110.5576317 & 808 & Subtropical scrub \\
24 & 29.9616575 & -110.5633822 & 885 & Subtropical scrub \\
25 & 29.9614781 & -110.5637147 & 885 & Subtropical scrub \\
26 & 29.9625306 & -110.5654203 & 832 & Subtropical scrub \\
27 & 29.9555517 & -110.5756583 & 788 & Subtropical scrub \\
28 & 29.9499750 & -110.5930811 & 742 & Desert scrub \\
29 & 29.9442386 & -110.6030522 & 696 & Desert scrub \\
30 & 29.9387650 & -110.6167411 & 669 & Desert scrub \\
\hline & & & &
\end{tabular}

tropical scrub, and oak savanna (SIUE-IMADES 1998). The topographic control on ecosystem distribution is a function of the temperature and rainfall conditions along the mountain slopes (e.g., Coblentz and Riitters 2004). For the observed transect elevations (670-1370 m), oak savanna represents the uppermost community $(>1200 \mathrm{~m})$. This ecosystem is part of the Madrean evergreen woodland and consists of individual trees, typically Emory oak (Quercus emoryi), interspersed with grasses and cacti (Brown 1994). A large elevation range (from 800 to $1200 \mathrm{~m}$ ) along steep slopes is occupied by a deciduous subtropical scrubland, known as Sinaloan thornscrub (Brown 1994). This ecosystem primarily consists of thorny trees and shrubs, such as Palo Verde (Cercidume sonorae) and Palo Blanco (Piscidia mollis), which leaf-on and become green during rainy periods. Valleys in this elevation range are occupied by mesquite (Prosopis juliflora) and other broadleaf evergreen trees. Low elevations $(<800$ $\mathrm{m})$ along the transect are composed of mixtures of drought-tolerant, desert trees, shrubs, and cacti, with subtropical scrubland species.

Figure $2 \mathrm{~b}$ shows the distribution of surface soils in the vicinity of the transect watershed based on the Food and Agriculture Organization (FAO) soils classification. Three major soil types are distinguished along the transect: lithosols (I), eutric regosols ( $\mathrm{Re})$, and eutric fluvisols (Je) (INIFAP 2001). At high elevations $(>900 \mathrm{~m})$, soils are classified as lithosols due to their limited depth and continuous, underlying bedrock composed primarily of Mesozoic granites and Tertiary rhyolites (SPP 1984). At intermediate elevations (from 700 to $900 \mathrm{~m}$ ), the soils are described as eutric regosols, which have no discernable horizonation and develop 


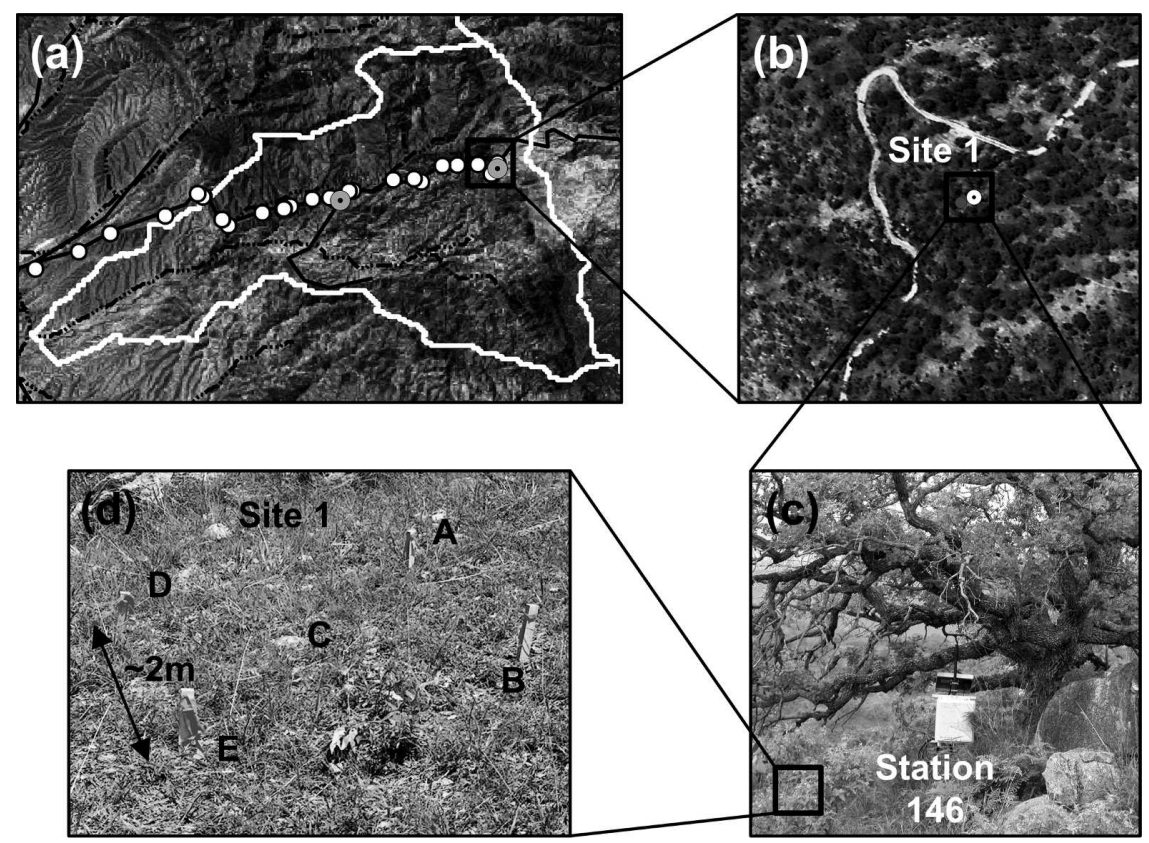

FIG. 3. Observational scales in the study. (a) Watershed and transect locations in a Landsat-5 Thematic Mapper (TM) image (55-m resolution) taken on 11 Jun 2004. (b) Aerial photograph (0.5-m resolution) of the high-altitude oak savanna taken from 1000-m elevation on 11 Aug 2004. Individual oak trees near site 1 can be distinguished. (c) Continuous recording station at site 1 (station 146) with a rain gauge and two soil moisture sensors (at 5- and 10 -cm depths). The instruments are placed $\sim 2 \mathrm{~m}$ from the oak tree in a grassy clearing. (d) Transect plot $(\sim 2 \mathrm{~m} \times 2 \mathrm{~m})$ established at site 1 to measure soil moisture and temperature at the five locations marked $A-E$. The plot was placed $\sim 1 \mathrm{~m}$ from the rainfall and soil moisture sensors. Atmospheric variables (air temperature, relative humidity, barometric pressure) were measured at each transect site.

over unconsolidated, Cenozoic conglomerates. Regions along ephemeral streams in this elevation range consist primarily of alluvium with large clasts present in the channels. At lower altitudes $(<700 \mathrm{~m})$, the soils consist of eutric fluvisols recently developed on Quaternary alluvium. Alluvial deposits are intermixed sediment, gravels, and boulders arising from the Sierra Aconchi. The north-south valley of the Río San Miguel contains a transmissive, shallow aquifer, which serves as the regional water supply (CNA 2002).

\section{b. Field campaign and instrumentation}

The field experiment was conducted during a 2-week period in early August 2004 to ensure that atmospheric conditions were favorable for convective events and their hydrologic response (e.g., Douglas et al. 1993; Adams and Comrie 1997). August is an important month for the regional hydroclimatology, as ephemeral stream discharge has been shown to be high and have a low interannual variability (Gochis et al. 2006). In addition, this month consists of infrequent, but intense mesoscale storms whose peak activity occurs during the late eve- ning and night (e.g., Gochis et al. 2004; Xie et al. 2005; Gebremichael et al. 2007). Sampling at 30 transect sites (Table 1; labeled from site 1 at the high altitude to site 30 at the low elevation) was performed daily from 3 to 14 August, over local times ranging from 0900 to 1600 LT to coincide with satellite and aircraft data acquisition schedules (SMEX Science Team 2004). While site sampling was not simultaneous, an attempt was made to make measurements at a similar time each day for each location. Early morning samples were typically taken at high altitudes along the transect, while later measurements were made at lower elevations. As a result, the manual field sampling was not designed to capture diurnal patterns at each transect site. Instead, we utilized a network of continuously recording sensors for this purpose (see descriptions below).

Figure 3 depicts the multiple observational scales in the transect study. Over the region, the field campaign was complemented by a permanent, ground-based sensor network and remote sensing data from aircraft and satellite platforms. This is illustrated in Fig. 3a by a Landsat-5 Thematic Mapper image over the transect 
basin. Aerial photographs along the rural road allow a closer inspection of the ecosystem communities (Fig. $3 b)$. Note that individual oaks are observed near site 1 due to the high image resolution $(\sim 0.5 \mathrm{~m})$. Site 1 contains a permanent sampling site (Fig. 3c), with a continuous rain gauge and two soil moisture sensors, as well as a transect plot $(\sim 2 \mathrm{~m} \times 2 \mathrm{~m})$ setup for daily sampling of hydrometeorological variables (Fig. 3d). Similar plots were established at the other transect sites in order to sample across a range of elevation and vegetation conditions (see Fig. 9a for depiction of elevations along the transect).

The following variables were measured in each transect site using hand-held instruments: soil moisture, soil temperature, air temperature, relative humidity, barometric pressure, and rainfall accumulation. Volumetric soil moisture $\left(\theta_{v}\right.$ in \%) was sampled from 0 to 6 $\mathrm{cm}$ using an impedance probe (Theta probe). The sensor uses a voltage standing wave method to estimate the relative probe impedance (Cosh et al. 2005), which is used to infer the soil moisture content. Five soil moisture readings were taken daily in each plot (see the letters $A-E$ in Fig. 3d). At each location, soil temperature $\left(T_{s}\right.$ in $\left.{ }^{\circ} \mathrm{C}\right)$ was measured at three depths $(\sim 1,5$, and $10 \mathrm{~cm}$ ) using a soil thermometer at the five sites. Atmospheric conditions were also determined near the plot at $\sim 1 \mathrm{~m}$ above the ground. Air temperature $\left(T_{a}\right.$ in ${ }^{\circ} \mathrm{C}$ ) and relative humidity ( $\mathrm{RH}$ in \%) were measured using a dial hygrometer-thermometer, while pressure $\left(P\right.$ in $\left.\mathrm{mm} \mathrm{Hg}^{-1}\right)$ was gauged using a barometer. Daily rainfall accumulation $\left(R_{d}\right.$ in $\left.\mathrm{mm}\right)$ at a subset of the transect sites was obtained using 10 event rain gauges. The sampling strategy is intended to capture the variability of a soil variable in each plot (via the five measurement sites) and over the transect (via the different locations), as well as the relation between soil and atmospheric conditions at each site.

The event rain gauges were used to complement continuous rainfall measurements at two transect locations (near sites 1 and 12). These permanent stations formed part of a ground-based network established over the region (Fig. 1b). During the campaign, rainfall was measured at 30-min intervals using a 6-in. tippingbucket gauge with a resolution of $0.2 \mathrm{~mm}$. The gauge rainfall rate $\left(R\right.$ in $\left.\mathrm{mm} \mathrm{h}^{-1}\right)$ has been quality-controlled at several locations with manual gauges. Volumetric soil moisture $\left(\theta_{v}\right.$ in \%) was estimated at 30-min intervals using a Hydra sensor. Each permanent site contained a moisture sensor at a 5 -cm depth (effective sampling from 3 to $7 \mathrm{~cm}$ ), while several locations have additional sensors at $10-$ and $15-\mathrm{cm}$ depths. Gravimetric soil moisture samples $\left(\theta_{g}\right.$ in \%) taken during the campaign $(0-3,3-6 \mathrm{~cm})$ have been used to quality control the surface volumetric estimates using the soil bulk density $\left(\rho_{b}\right)$ for each site.

The field campaign measurements were supplemented by an extensive characterization of each site for the following properties: geographic location, terrain attributes, ecosystem type, and soil condition. A global positioning system (GPS) sensor, compass, and clinometer were used to obtain the location, elevation, aspect, and slope of each transect site. Ecosystem properties, including vegetation species and plant cover, were documented via digital photography and identified using field books (Brown 1994; Paredes-Aguilar et al. 2000). Field measurements and laboratory analysis of soil characteristics were made to determine texture, rock fraction, bulk density, and surface roughness (SMEX Science Team 2004). Ground observations were used to augment data layers collected over the region and archived in a geographical information system (GIS).

\section{c. Measurement intercomparisons}

The sampling methods used during the field campaign were compared in order to gain confidence in the dataset prior to further interpretations. Figure 4 presents an example of the soil moisture and temperature derived via different techniques over similar depths at station 146 (site 1). In Fig. 4a, the soil moisture $\left(\theta_{v}\right.$ in $\%$ ) from the Hydra sensor is compared to the Theta probe and gravimetric samples. The techniques indicate a general drying trend at the site, with a brief increase in soil moisture observed due to a rainfall event. Theta probe soil moisture estimates follow the Hydra sensor record quite well and typically bound the values within the observed plot-scale variability. Figure $4 \mathrm{~b}$ presents a comparison of the soil temperature from the Hydra sensor and the soil thermometer readings. Note the strong diurnal fluctuations in soil temperature and the excellent correspondence between the techniques. Only the continuous sensor identified a decrease in soil temperature after the rainfall event. These comparisons indicate that the daily sampling strategy appears adequate for capturing soil moisture trends, but care should be taken when interpreting soil temperature data that exhibit high diurnal fluctuations.

\section{Results}

In the following, we utilize the continuous and daily measurements to assess the variation of hydrometeorological conditions along the topographic transect. We focus the analysis on the spatial and temporal variabilities of soil moisture and the potential linkage between 

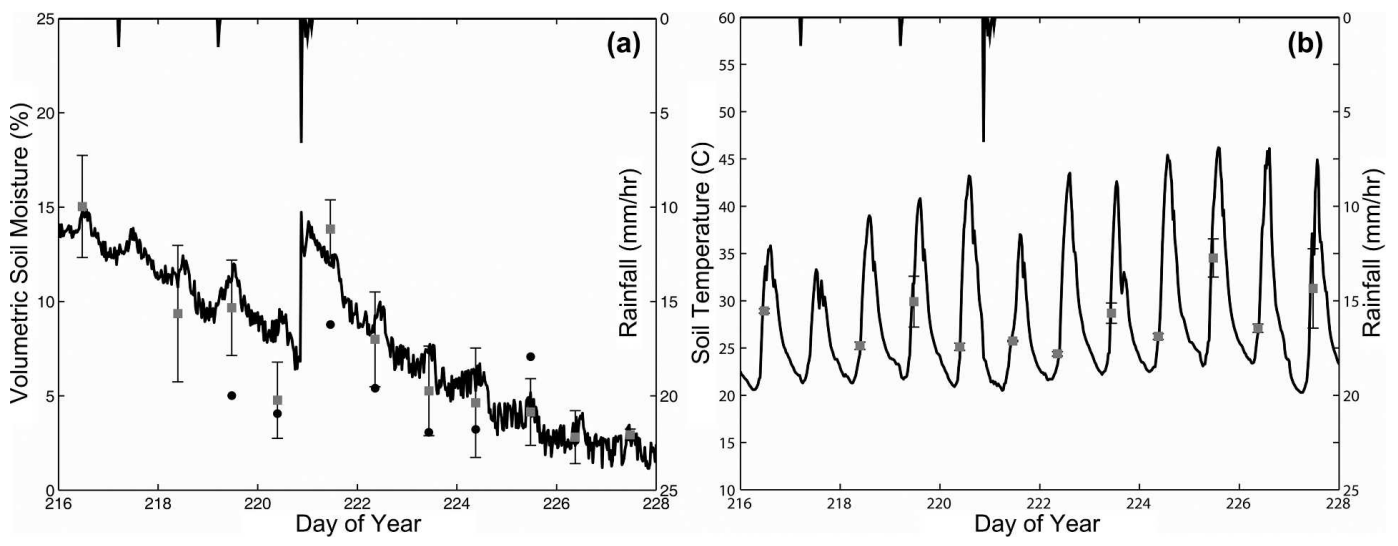

FIG. 4. Comparison of sampling methods for hydrometeorological variables along a topographic transect for collocated site 1 and station 146 during 3-14 Aug 2004 (Julian days 216-227). (a) Rainfall rate ( $\mathrm{mm} \mathrm{h}^{-1}$ ) and volumetric soil moisture (\%) estimated via three methods: $5-\mathrm{cm}$ depth Hydra sensor (continuous solid line), 0-6-cm Theta probe estimates (squares with error bars depicting the mean value \pm 1 std dev for five daily measurements), and 0-6-cm gravimetric samples (closed circles). (b) Rainfall rate (in $\mathrm{mm} \mathrm{h}^{-1}$ ) and soil temperature $\left({ }^{\circ} \mathrm{C}\right)$ estimated via two methods: 5-cm depth Hydra sensor (continuous solid line) and 5-cm soil thermometer readings (squares with error bars depicting the mean value \pm 1 std dev for five daily measurements). Soil temperature is an additional measurement made by the Hydra sensor to estimate volumetric soil moisture. Note that the soil moisture estimate from the Hydra sensor has a diurnal fluctuation that may be due to measurement errors arising from the large fluctuations in soil temperature (e.g., Seyfried and Murdock 2004).

soil and atmospheric conditions. Field data are selected for representative sites with nearly complete temporal coverage in the major ecosystems and during days with extensive spatial coverage. Based on these observations, we estimate the temporal variability of basinaveraged conditions. The averaging technique accounts for the topographic variability within a $100 \mathrm{~km}^{2}$ basin in the Río San Miguel. Prior to presenting the transect data, we describe the regional rainfall and soil moisture conditions over the period of 1 July-31 August 2004 to provide a larger-scale and longer-term context for our observations.

\section{a. Regional hydrometeorological conditions}

The North American monsoon has a significant control on the hydrometeorology of the mountainous region in northern Mexico as indicated by rainfall and streamflow records (e.g., Brito-Castillo et al. 2003; Gochis et al. 2006). For the study area, climate records at Opodepe (elevation $640 \mathrm{~m}$ ) indicate that $53 \%$ of the annual precipitation $(477 \mathrm{~mm})$ occurs during July and August. Figure 5 presents the monthly distribution of rainfall $(\mathrm{mm})$ and maximum and minimum air temperatures $\left({ }^{\circ} \mathrm{C}\right)$ over the period $1975-2000$. Note the low precipitation and increasing maximum temperatures during April-June, prior to the monsoon onset in July. The monsoon season (July-September) experiences a large increase in rainfall and a small reduction in maximum air temperature, potentially due to cloudiness and changes in surface conditions (e.g., vegetation, soil tem- perature, and moisture). The timing of the monsoon onset and the higher rainfall amounts for July $(133 \mathrm{~mm})$ as compared to August $(120 \mathrm{~mm})$ at this station agree well with the observed gradient in the climatological characteristics as distance increases away from the core region of the monsoon domain (e.g., Xu et al. 2004a; Gutzler 2004).

The spatial variability of monsoon rainfall during July and August 2004 can be obtained from the rain gauge network. Figure 6 presents the rainfall amounts at 12 rain gauges in the $75 \mathrm{~km} \times 50 \mathrm{~km}$ domain over (a)

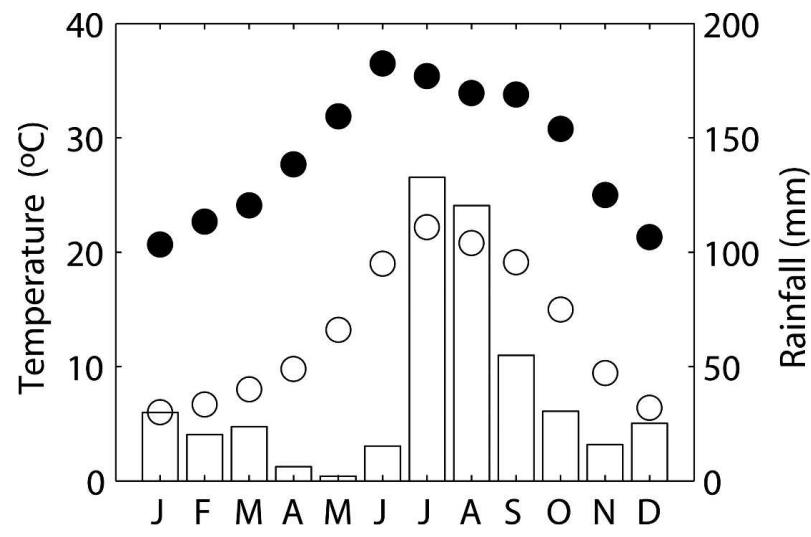

FIG. 5. Hydroclimatology of the transect region obtained from long-term weather observations at Opodepe, Sonora. The weather station is located at $29.93^{\circ} \mathrm{N},-110.63^{\circ} \mathrm{W}$ and $640 \mathrm{~m}$ (elevation). Mean annual rainfall (bars in $\mathrm{mm}$ ) and maximum (closed circles) and minimum (open circles) monthly air temperatures $\left({ }^{\circ} \mathrm{C}\right)$ over the period $1975-2000$. 

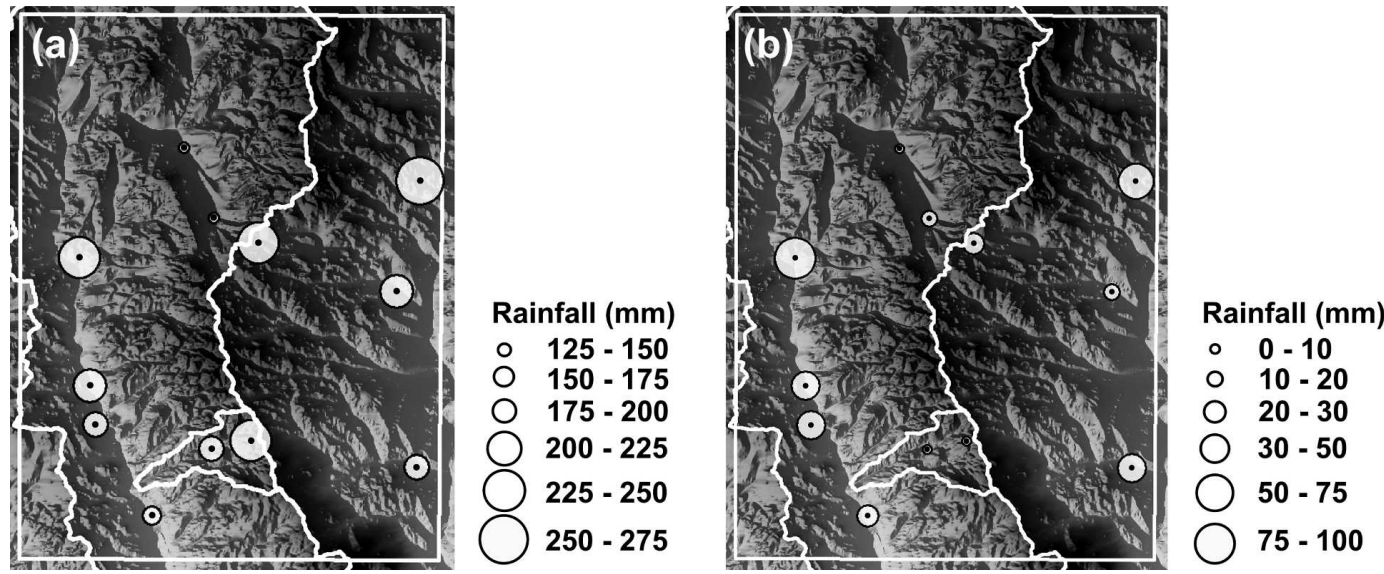

FIG. 6. Regional distribution of precipitation from ground-based rain gauge network. (a) Rainfall accumulation (mm) from 1 Jul to 31 Aug 2004. (b) Rainfall accumulation (mm) during the field campaign from 3 to 14 Aug 2004. Note that the symbol size depicts the total rainfall amount for each time period, as indicated in the two legends.

1 July-31 August and (b) 3-14 August. Two gauging sites (stations 136 and 138) were not used due to missing data affecting the total accumulations. Note the July-August totals in Fig. 6a indicate that the spatial distribution is controlled by elevation and relative position along a river valley. A decreasing trend is observed at lower elevations and for sites farther south in the domain. The observed spatial variability $(132-258 \mathrm{~mm})$ is consistent with climatological values at long-term stations in the region (e.g., Brown 1994). Total JulyAugust rainfall amounts in the transect basin (stations 132 and 146) are also comparable to the regional observations. In particular, the higher-elevation station (site 1 or station 146: $225 \mathrm{~mm}$ ) received more rainfall as compared to the midelevation site (site 12 or station 132: $189 \mathrm{~mm}$ ). Gebremichael et al. (2007) present additional details on the spatial distribution of rainfall statistics in the domain and identify four rainfall subregions based on spatial coherency (Sierra Aconchi, Cucurpe, Río San Miguel valley, and Río Sonora valley).

As shown in Fig. 6b, rainfall accumulation during the field campaign was significantly reduced as compared to the July-August totals, in particular over the transect basin. Note the maximum rainfall amounts occurred at station 144 in the Río San Miguel $(100 \mathrm{~mm})$ as a result of a major storm that led to flooding in the ephemeral river. In comparison, transect stations 132 and 146 received $\sim 7 \mathrm{~mm}$ during the campaign with no discernable difference due to elevation. The hydrometeorological conditions are further explored in Fig. 7, which presents the temporal variability of rainfall $\left(\mathrm{mm} \mathrm{h}^{-1}\right)$ and soil moisture (\%) at two sites, as well as the daily discharge $\left(\mathrm{m}^{3} \mathrm{~s}^{-1}\right)$ at the El Cajón gauge. Station 144 is located in the northern valley of the Río San Miguel (799 m), while station 146 is located in the upper transect (1371 $\mathrm{m})$. Comparisons of the rainfall records demonstrate the effect of elevation on rainfall amounts, with the mountain site receiving frequent, small events, while the valley site is dominated by larger, infrequent storms (see Gebremichael et al. 2007 for detailed statistical analysis). This is consistent with Gochis et al. (2004) who showed that single convection cells were common at high elevations, while mesoscale convective complexes characterize lower elevations.

Temporal differences in the rainfall characteristics are reflected in the soil moisture and discharge measurements. Note the correspondence between the rainfall rate at station 144 and the streamflow record, indicating that intense precipitation over the river valley has a strong linkage to flood generation. In contrast, the mountain site is more weakly correlated to discharge, as single-cell storms are less capable of generating flooding. To corroborate this observation, a comparison of the runoff ratio $(Q / P)$ reveals a higher value for the valley site as compared to the mountain station (Fig. 7). Furthermore, the rainfall-runoff relation between upland areas and the lowland river is weaker as hillslope and channel losses are anticipated to be high in the region (Descroix et al. 2002a). This is particularly evident during the field campaign, as denoted by the vertical dashed lines. In this period, the transect site experiences low rainfall amounts and a declining soil moisture, while the valley site exhibits an overall increase in soil moisture due to a major storm on 11 August (day 224). It is apparent from the observations that the topographic transect experienced high rainfall amounts prior to the field campaign, which were comparable to regional accumulations, and a general drying trend during the sampling period. This drying trend 

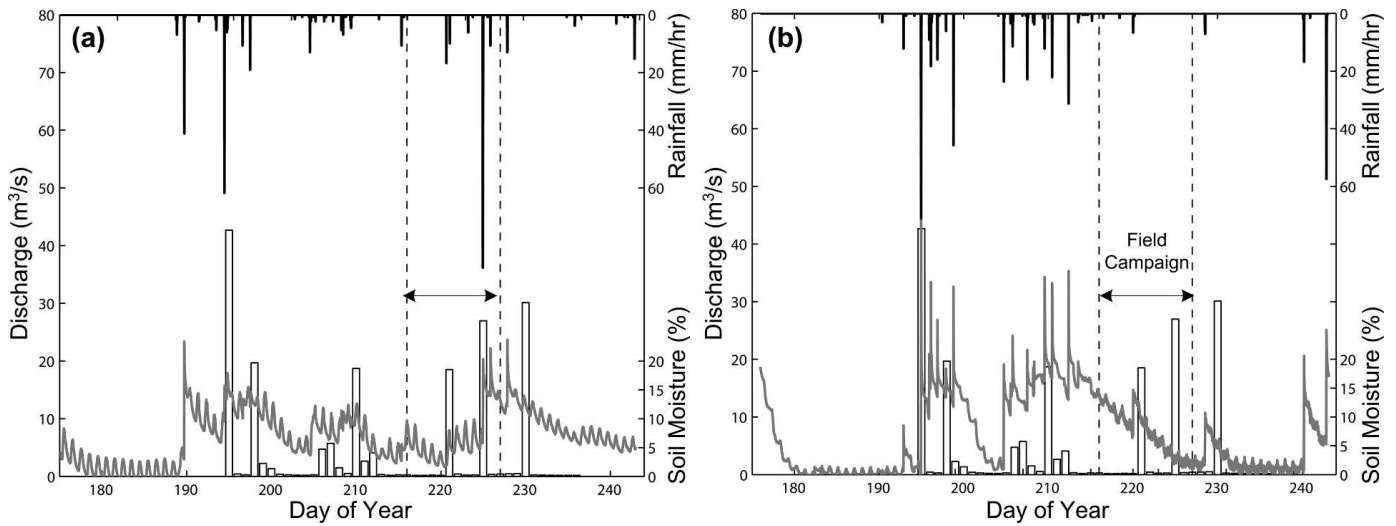

FIG. 7. Regional and topographic transect observations of rainfall, soil moisture, and stream discharge. The daily stream discharge $\left(\mathrm{m}^{3} \mathrm{~s}^{-1}\right.$, bar plots) was measured at the El Cajón gauging site on the Río San Miguel by CNA (2004) over period 13 Jul-23 Aug 2004. Comparison of 30-min rainfall accumulation (in $\mathrm{mm} \mathrm{h}^{-1}$ ) and volumetric soil moisture (\%) estimated from the 5-cm depth soil moisture sensor for (a) station 144, a regional site receiving large rainfall amounts ( $99.57 \mathrm{~mm}$ during field campaign), and (b) station 146, collocated with site 1 in the topographic transect. The dashed vertical lines represent the time period of the field campaign (3-14 Aug 2004). See Fig. $1 \mathrm{~b}$ for location of stations and stream gauging site. The runoff ratio $(Q / P$, where $Q$ and $P$ are the daily discharge and rainfall volumes) was estimated for each site based on the outlet discharge and the rainfall record at each station. For station 144 (valley site), $Q / P=0.023$, while for station 146 (mountain site), $Q / P=0.017$. This suggests a stronger relationship between the rainfall accumulation and outlet discharge in the valley region.

appears limited to a broad mountainous area as the river valley experienced large mesoscale storms during the field campaign.

\section{b. Spatial and temporal soil moisture variability over topographic transect}

The topographic variations of hydrometeorological variables are poorly understood in the NAM region (e.g., Higgins et al. 2003; Gochis et al. 2004), primarily due to the lack of detailed observations along elevational gradients. The topographic transect from Opodepe $(669 \mathrm{~m})$ to the summit of Sierra Aconchi $(1371 \mathrm{~m})$ provides a unique opportunity to understand the temporal and spatial variabilities in hydrologic response to monsoon rainfall. In the following, we present a subset of the field campaign dataset that captures the variation of rainfall and soil moisture as a function of time at four sites and as a function of elevation during three sampling dates. Note that the analysis is based on measurements of surface soil moisture $(0-6 \mathrm{~cm})$ using the Theta probe in each transect site. We present the plot average (as symbols) and standard deviation (as bars) based on five measurements at each site to assess the variability in a plot and over the transect.

Figure 8 presents the temporal variability of the surface soil moisture at four sites along the transect: site 1 (oak savanna, $1371 \mathrm{~m}$ ), site 12 (subtropical scrub, 916 $\mathrm{m}$ ), site 16 (mesquite forest, $825 \mathrm{~m}$ ), and site 30 (desert scrub, $669 \mathrm{~m}$ ). Continuous rainfall records at station 146 and 132 are depicted for nearby sites 1 and 16. Station 132 is also applicable to site 12; while a rain gauge is not available at site 30 . Note the correspondence between rainfall and soil moisture response, in particular for sites 1 and 16. For example, a small storm of $\sim 6 \mathrm{~mm}$ $\mathrm{h}^{-1}$ leads to an increase in soil moisture from $\sim 5 \%$ to $14 \%$ in site 1 (day 221). Interestingly, the increase in soil moisture is short lived, with values returning to prestorm levels in $\sim 2$ days. This suggests that surface moisture is rapidly depleted by evapotranspiration, soil infiltration, and downslope lateral fluxes. The soil moisture recession follows an exponential decay after a storm event, in particular for the latter periods in sites 1 and 30. This agrees well with surface moisture recessions (decay constants of $\sim 2$ days) observed in New Mexico during the NAM (Kurc and Small 2004).

A comparison of the soil moisture amount and its variability at the four sites can provide an indication of the differences in hydrologic response in each ecosystem. Note that the oak savanna (site 1) and mesquite forest (site 16) have high soil moisture values, but also large temporal variability ( $\sim 2 \%$ to $\sim 15 \%)$. In contrast, the subtropical and desert scrubs (sites 12 and 30) exhibit low soil moisture and reduced day-to-day variations $(\sim 5 \%$ to $\sim 10 \%)$. Several factors may control the observed soil moisture distributions, including rainfall, terrain position, vegetation type, and soil properties (Rodríguez-Iturbe 2000). While these are all strongly 

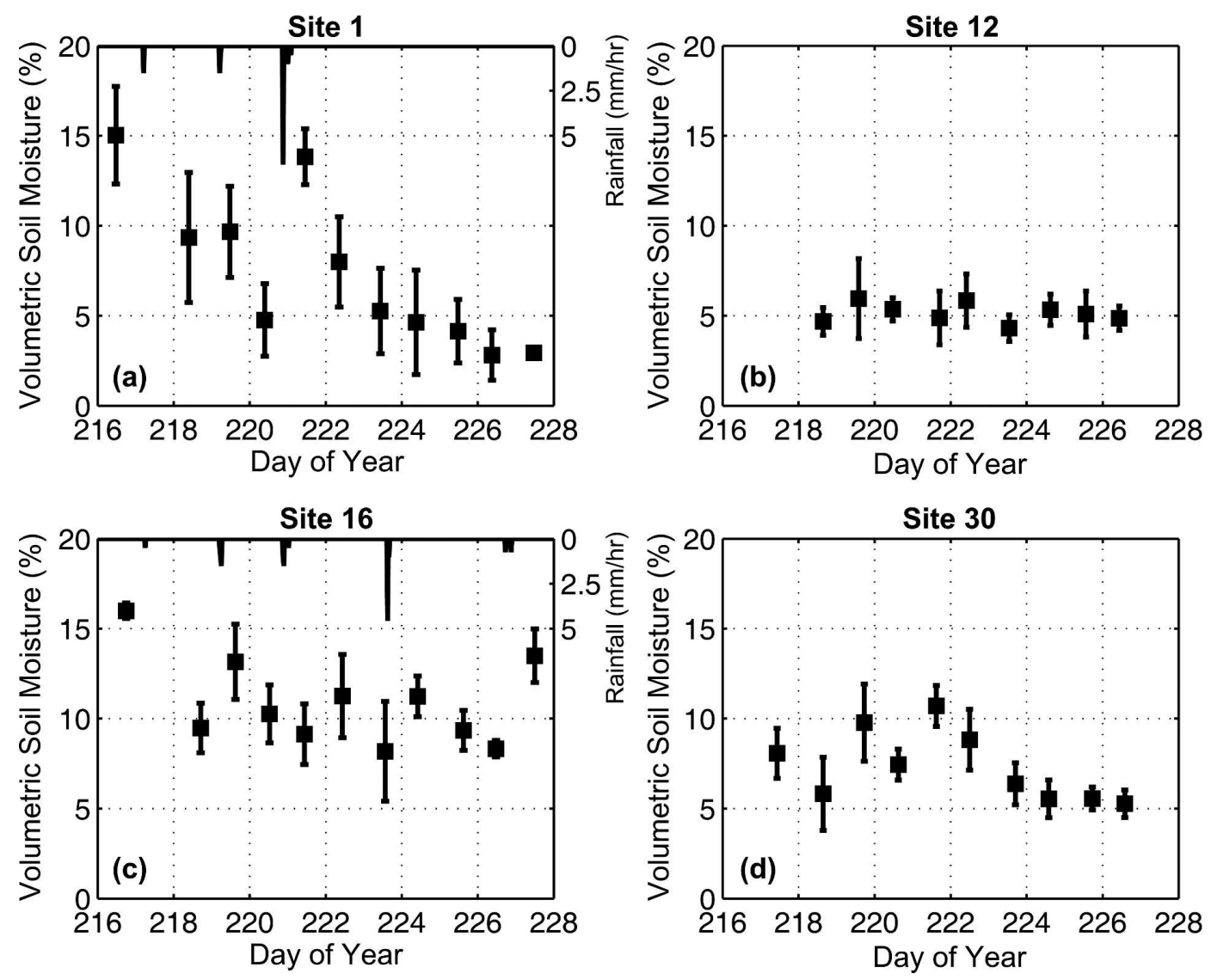

FIG. 8. Temporal variability in soil moisture at sites along the topographic transect (3-14 Aug 2004, Julian days 216-227). For each day, the plot average (square) of volumetric soil moisture (\%) obtained from the Theta probe sensor $(0-6 \mathrm{~cm})$ is shown with \pm 1 std dev (vertical bars). Values are plotted to nearest 30-min interval. Shown are (a) site 1 in oak savanna (elevation $1371 \mathrm{~m}$ ) with rainfall rate $\left(\mathrm{mm} \mathrm{h}^{-1}\right)$ from nearby station 146 , (b) site 12 in subtropical scrub (elevation $916 \mathrm{~m}$ ), (c) site 16 in mesquite forest (elevation $825 \mathrm{~m}$ ) with rainfall rate $\left(\mathrm{mm} \mathrm{h}^{-1}\right.$ ) from nearby station 132, and (d) site 30 in desert scrub (elevation $669 \mathrm{~m}$ ). Note that station 132 is representative for site 12; no representative rainfall observations are available for site 30 .

interrelated, topography is considered a dominant variable in mountain areas (Coblentz and Riitter 2004). For example, the oak savanna and mesquite forest have access to moisture due to increased rainfall at high altitude and flow convergence in valleys. In contrast, the subtropical scrub has low, nearly constant soil moisture as it is found along steep slopes at midelevations. Further differences are observed in the plot-scale variability at each site. Note the variations inside a plot $(\sim 4$ $\mathrm{m}^{2}$ ) can be higher for the forest ecosystems (sites 1 and 16) as compared to the drier scrublands (sites 12 and 30). At certain transect sites (sites 12 and 30), plot-scale variability at a location can be of similar magnitude to the temporal variations over the period (Table 2).

Figure 9 shows the spatial variability of surface soil moisture along the elevation transect during three sampling dates: days 218 (5 August), 221 (8 August), and 224 (11 August). Days were selected to ensure com- plete spatial coverage and depict the evolution of the moisture field in relation to storm periods (days 221 and 224). For reference, Fig. 9a presents the elevation at the 30 transect sites (not to scale in the horizontal direction). To assess the spatial variability in soil moisture, it is useful to consider several regions along the transect: mountain (sites 1-6), slope (sites 7-9), footslope (sites 10-13), valley (sites 14-22), hill (sites 2326), and lower valley (sites 27-30). These regions were selected based on observed landforms in the field and topographic data analysis (e.g., GPS points along transect and 90-m DEM). Terrain elevation decreases sharply over the mountain, slope, and footslope regions, while similar altitudes are present in the valley and lower valley regions. A more detailed description of the terrain variability within the transect is presented in section $3 \mathrm{~d}$.

The topographic regions aid in understanding how 
TABLE 2. Comparison of temporal and plot-scale variability of volumetric soil moisture. The temporal variability captures the day-to-day variations at a site. The mean and std dev are (a) the time average of the plot-average soil moisture (symbols in Fig. 8), represented by $\overline{\left\langle\theta_{v}\right\rangle}$ (brackets are plot average; overbar is time average), and (b) the std dev of the plot-average soil moisture over the period or $\left\langle\theta_{v}\right\rangle^{\prime}$ (brackets are plot average; apostrophe is plot temporal std dev). The plot-scale variability captures the variations within a plot as a function of time. The mean and std dev are (c) the time average of the plot-scale std devs (bars in Fig. 8 ), represented as $\overline{\theta_{v}^{\prime}}$ (apostrophe is plot spatial std dev; overbar is time average), and (d) the std dev of the plot-scale std devs over the period or $\theta_{v}^{\prime \prime}$ (apostrophes are plot spatial and temporal std dev). Note that at certain locations (e.g., sites 12 and 30), the temporal mean of the plot-scale variability $\left(\overline{\theta_{v}^{\prime}}\right)$ can be of the same magnitude as the temporal variability of the plot average soil moisture $\left(\left\langle\theta_{v}\right\rangle^{\prime}\right)$.

\begin{tabular}{cccccc}
\hline \hline \multirow{2}{*}{$\begin{array}{c}\text { Transect } \\
\text { site }\end{array}$} & \multicolumn{2}{c}{ Temporal variability (\%) } & & \multicolumn{2}{c}{ Plot-scale variability (\%) } \\
\cline { 2 - 3 } \cline { 5 - 6 } & Mean & Std dev & & Mean & Std dev \\
\hline 1 & 7.31 & 4.24 & & 2.15 & 0.88 \\
12 & 5.14 & 0.53 & & 1.13 & 0.53 \\
16 & 10.90 & 2.45 & & 1.50 & 0.72 \\
30 & 7.34 & 1.94 & & 1.29 & 0.52 \\
\hline
\end{tabular}

soil moisture varies with elevation and if clear distinctions are observed between landforms (e.g., mountain versus valley). For example, there are sharp differences in soil moisture for day 218 as altitude decreases from the mountain to the lower valley. Note that the mountain region is characterized by high soil moisture $(\sim 10 \%-15 \%)$, which exhibit large plot-scale variability, but small site-to-site differences. Soil moisture means decrease considerably in the slope and footslope areas $(\sim 2 \%-8 \%)$, with a decrease in plot-scale variability and a small increase in site-to-site differences. Farther downslope in the valley region, a large variation in soil moisture statistics is observed as the proximity to channels and hillslopes influences moisture conditions. In one location (site 17) at the bottom of a long slope, soil moisture is consistently high, but exhibits high plotscale variability. Neighboring sites in the valley have moderate soil moisture means $(\sim 7 \%-12 \%)$, low plotscale variability at a site, and high site-to-site differences across the transect. Note that the plot-scale variability can be of similar magnitude to the spatial variations during certain periods (e.g., day 224 in Table 3).
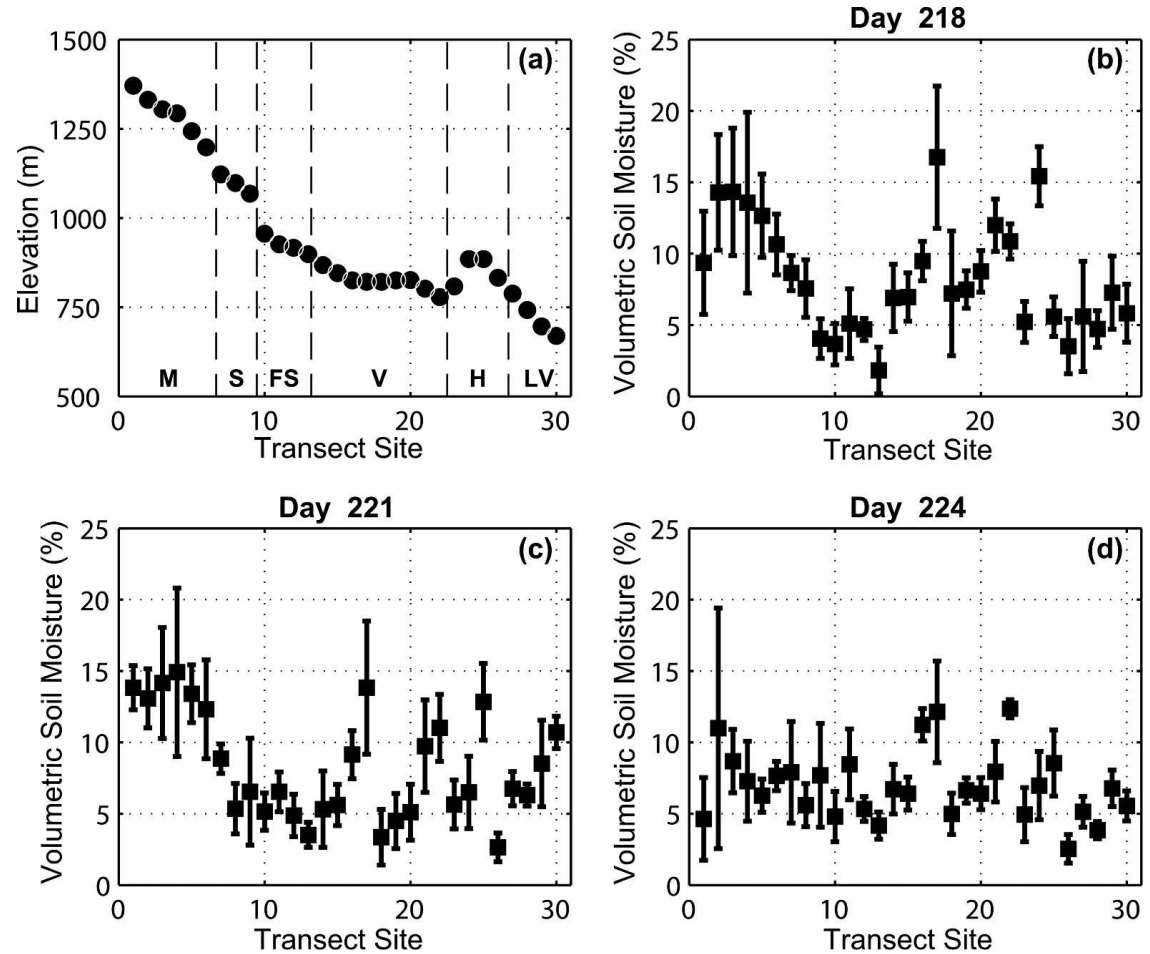

FIG. 9. Spatial variability in soil moisture at sites along the topographic transect. For each day, the plot average (square) of volumetric soil moisture (\%) obtained from the Theta probe sensor $(0-6 \mathrm{~cm})$ is shown with \pm 1 std dev (vertical bars). (a) Elevation $(\mathrm{m})$ at each transect site (numbered 1-30) obtained from a GPS sensor. Note the landforms labeled along the transect: M (mountain), S (slope), FS (footslope), V (valley), H (hill), and LV (lower valley). Shown are days (b) 218 (5 Aug), (c) 221 (8 Aug), and (d) 224 (11 Aug 2004). 
TABLE 3. Comparison of the spatial and plot-scale variabilities of volumetric soil moisture $\left(\theta_{v}\right.$ in \%) over the transect during 3 days. The spatial variability captures the site-to-site variations during a particular day. The spatial mean (via simple averaging) and std dev are (a) the spatial average of the plot-average soil moisture (symbols in Fig. 9), represented by $\left\langle\left\langle\theta_{v}\right\rangle\right\rangle$ (brackets are plot and transect averages), and (b) the std dev of the plot-average soil moisture over all transect sites or $\left\langle\theta_{v}\right\rangle^{\prime}$ (brackets are plot average; apostrophe is transect spatial std dev). The plot-scale variability captures the variations within a plot as a function of transect sites. The mean and standard deviation (std dev) are (c) the spatial average of the plot-scale standard deviations (bars in Fig. 9), represented as $\left\langle\theta_{v}^{\prime}\right\rangle$ (apostrophe is plot spatial std dev; brackets are transect average), and (d) the std dev of the plotscale standard deviations over all the transect sites or $\theta_{v}^{\prime \prime}$ (apostrophes are plot and transect spatial std dev). Note in certain days (e.g., day 224) the spatial mean of the plot-scale variability $\left(\left\langle\theta_{v}^{\prime}\right\rangle\right)$ can be of the same magnitude as the spatial variability of the plot-average soil moisture $\left(\left\langle\theta_{v}\right\rangle^{\prime}\right)$.

\begin{tabular}{cccccc}
\hline \hline \multirow{2}{*}{$\begin{array}{c}\text { Sampling } \\
\text { day }\end{array}$} & \multicolumn{2}{c}{ Spatial variability $(\%)$} & & \multicolumn{2}{c}{ Plot-scale variability (\%) } \\
\cline { 2 - 3 } \cline { 5 - 6 } & Mean & Std dev & & Mean & Std dev \\
\hline 218 & 8.33 & 3.93 & & 2.39 & 1.35 \\
221 & 8.33 & 3.78 & & 2.22 & 1.20 \\
224 & 6.95 & 2.40 & & 1.96 & 1.51 \\
\hline
\end{tabular}

Although many factors influence soil moisture, it is clear that elevation helps explain much of the observed variability in the transect.

A comparison of the sampling days illustrates the temporal evolution of the soil moisture patterns along the transect. Two storms of limited extent and duration occurred prior to day 221 (near the mountain region) and day 224 (near the footslope and valley regions) (Figs. 8a-c). Superimposed on these small events is a general surface drying as major storms occurred before the campaign (Fig. 7). Note the overall trend toward homogenous soil moisture across the transect as time progresses. The mountain region, having received minor rain amounts on day 221 , dries considerably by day 224. The slope and footslope areas are wet after both storms and retain high moisture by day 224 . The valley region (site 16) dries between days 219 and 221 and increases in soil moisture by day 224 in response to the storm and lateral moisture fluxes. As a result, the spatial pattern in soil moisture shows a consistent movement away from clearly distinguished regions (day 218), toward similar values across all elevations, approaching $\sim 7 \%$ on day 224 . This indicates that elevation is an important factor during wet periods resulting from rainfall, but that its effects are diminished as a landscape adjusts to the rainfall event (e.g., drying in several regions, wetting in other parts). The reduction of terraininduced soil moisture variations during drying has also

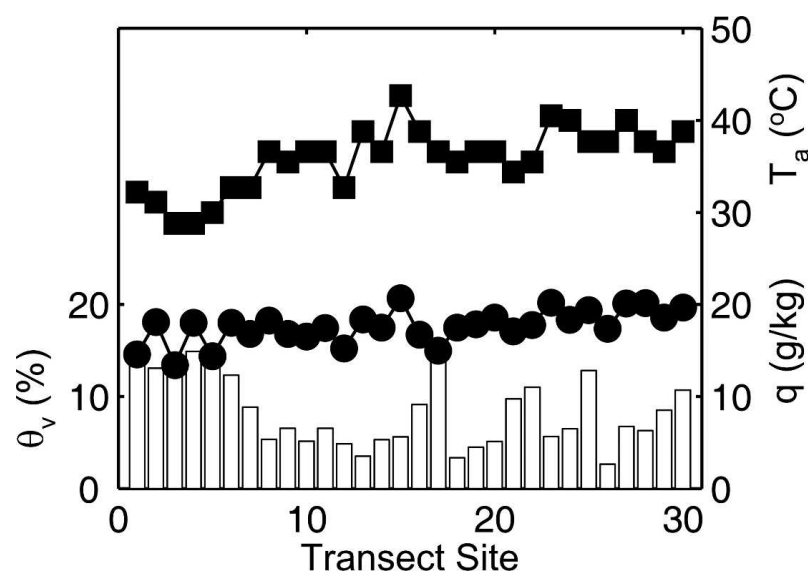

FIG. 10. Example of the spatial variability in hydrometeorological variables at sites along the topographic transect (sites 1-30). The variation in volumetric soil moisture $\left[\theta_{v}(\%)\right.$, bars] from Theta probe sensor (plot average shown), specific humidity $[q$ (g $\left.\mathrm{kg}^{-1}\right)$ closed circles] , and $\left[T_{a}\left({ }^{\circ} \mathrm{C}\right.\right.$, closed squares $\left.)\right]$ presented for 8 Aug 2004 (day 221). See Fig. 9a for the transect site elevations.

been observed at a smaller scale by Famiglietti et al. (1998).

\section{c. Relations between soil and atmospheric conditions over topographic transect}

Land surface conditions are anticipated to play an important role in modulating rainfall during the North American monsoon (e.g., Higgins et al. 2003; Zhu et al. 2005). Nevertheless, observations of soil and atmospheric conditions in the NAM region are lacking, in particular for mountain areas. We conducted simultaneous sampling of atmospheric properties $(\sim 1 \mathrm{~m}$ above soil) in each plot. As an example, Fig. 10 shows the transect profile of soil moisture $\left(\theta_{v}\right.$ in $\left.\%\right)$, air temperature $\left(T_{a}\right.$ in $\left.{ }^{\circ} \mathrm{C}\right)$, and specific humidity $\left(q\right.$ in $\left.\mathrm{g} \mathrm{kg}^{-1}\right)$ during day 221 (8 August). Specific humidity is computed using the sampled relative humidity, pressure, and air temperature. It is a more appropriate measure of water vapor not affected by changes in air temperature (Rogers and Yau 1989). Note the low degree of spatial variability in the atmospheric conditions as compared to soil moisture. The small, progressive increase in $T_{a}$ and $q$ from sites 1 to 30 is due to a combination of sampling at later times during the day (i.e., diurnal cycle) and the effect of elevation on air temperature (i.e., ambient lapse rate). Minor variations between closely located sites are also expected due to shading and transpiration effects in different ecosystems.

Figure 11 presents a comparison of soil and atmospheric conditions at four sites along the transect, selected because they have a complete temporal record 

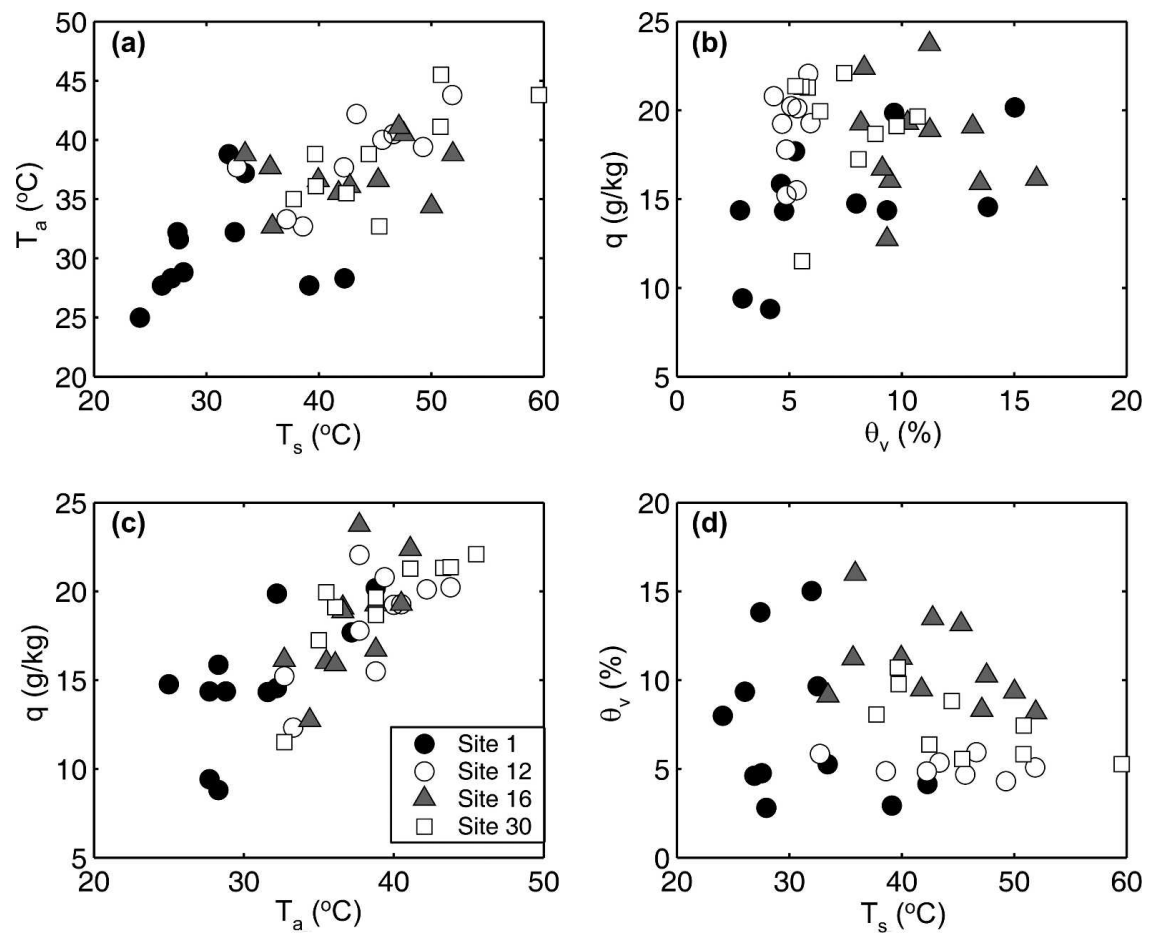

FIG. 11. Daily relations between measured soil and atmospheric variables at four transect sites representing different landscape positions and ecosystems (site 1, closed circles; site 12, open circles; site 16, closed triangles; site 30, open squares). Refer to Fig. 8 for the temporal variation in soil moisture at each site. Shown are (a) air $T_{a}\left({ }^{\circ} \mathrm{C}\right)$ vs $T_{s}\left({ }^{\circ} \mathrm{C}\right)$, (b) specific $q(\mathrm{~g}$ $\left.\mathrm{kg}^{-1}\right)$ vs $\theta_{v}(\%),(\mathrm{c}) q\left(\mathrm{~g} \mathrm{~kg}^{-1}\right)$ vs $T_{a}\left({ }^{\circ} \mathrm{C}\right)$, and (d) $\theta_{v}(\%)$ vs $T_{s}\left({ }^{\circ} \mathrm{C}\right)$. Each symbol depicts a pair of measurements for a particular day at each site. For each soil variable $\left(\theta_{v}, T_{s}\right)$ the plot average is utilized.

and are representatives of different elevation bands and vegetation types (see section $3 \mathrm{~b}$ for site selection). We relate air conditions $\left(T_{a}, q\right)$ to corresponding soil properties $\left(T_{s}, \theta_{v}\right)$ (Figs. 11a and 11b) and compare moisture amounts $\left(q, \theta_{v}\right)$ to temperatures $\left(T_{a}, T_{s}\right)$ in each medium (Figs. 11c and 11d). Each point represents a pair of values for a specific day. Points at the same site (same symbol) tend to cluster in the measurement space. Overall, a strongly linear positive relation is observed between $T_{a}$ and $T_{s}$, while a weakly linear positive trend exists between $q$ and $\theta_{v}$ (Table 4). The increase in $q$ with $\theta_{v}$ is indicative of the soil moisturerainfall feedback mechanism proposed by Eltahir (1998). The stronger $T_{a}-T_{s}$ relation is expected as the lower air in contact with a surface can equilibrate more quickly with respect to temperature than moisture (Entekhabi 1995). Note that the orographic effects on temperature and moisture are embedded within the relations. Furthermore, local controls in particular ecosystems can have an important effect on site-specific interactions. For example, the subtropical scrub can sustain high $q$ despite having low $\theta_{v}$, an important ecosystem contribution to moisture recycling back to the atmosphere. The observed land-atmosphere coupling suggests that surface conditions ( $T_{s}$ and $\theta_{v}$ ) may play an important role in heating and moistening the lower atmosphere with implications for rainfall generation during the monsoon (Eltahir 1998; Small and Kurc 2003).

Analysis of atmospheric $\left(T_{a}, q\right)$ and soil $\left(T_{s}, \theta_{v}\right)$ conditions is helpful in assessing site controls on landatmosphere relations (Table 4). Note the positive, linear trend between $q$ and $T_{a}$ and the site clustering in the measurement space. As $q$ does not change with $T_{a}$, the linear trend results from varying conditions over the transect during a day. Elevated regions have lower $T_{a}$ and $q$ (site 1, sampled early), while lower altitudes have higher $T_{a}$ and $q$ (site 30, sampled late). This suggests the ambient lapse rate and diurnal cycle lead to warmer, more humid conditions at low elevations later during the day. For the soil properties, an overall trend between $\theta_{v}$ and $T_{s}$ is not apparent, although site relations indicate lower $T_{s}$ for higher $\theta_{v}$, (and vice versa), particularly for sites 16 and 30. A decrease in $T_{s}$ with increasing $\theta_{v}$ is a second component of the soil moisture-rainfall feedback mechanism proposed by Eltahir (1998). The relation between $T_{s}$ and $\theta_{v}$ is expected to be 
TABLE 4. Linear regression statistics for land-atmosphere relations (sites 1,12, 16, and 30) and for their combination (e.g., four sites). The slope $(S)$ and intercept $(I)$ are the parameters of the linear regression in the units of measurement for each relation [e.g., $T_{a}-T_{s}$ has $S\left({ }^{\circ} \mathrm{C}^{\circ} \mathrm{C}^{-1}\right)$ and $\left.I\left({ }^{\circ} \mathrm{C}\right)\right]$.

\begin{tabular}{lccrc}
\hline \hline Relation & Site & $\begin{array}{c}\text { Slope } \\
\text { (units units }\end{array}{ }^{-1}$ ) & $\begin{array}{c}\text { Intercept } \\
\text { (units) }\end{array}$ & $R^{2}$ \\
\hline$T_{a}-T_{s}$ & 1 & 0.11 & 27.33 & 0.02 \\
& 12 & 0.44 & 19.79 & 0.51 \\
& 16 & 0.11 & 32.45 & 0.07 \\
& 30 & 0.44 & 18.30 & 0.54 \\
$q-\theta_{v}$ & Combination & 0.42 & 19.30 & 0.51 \\
& 1 & 0.49 & 11.36 & 0.33 \\
& 12 & 0.71 & 15.25 & 0.03 \\
& 16 & -0.21 & 20.47 & 0.03 \\
& 30 & 0.03 & 19.02 & 0.00 \\
$q-T_{a}$ & Combination & 0.16 & 16.45 & 0.03 \\
& 1 & 0.56 & -2.15 & 0.43 \\
& 12 & 0.61 & -5.47 & 0.51 \\
& 16 & 0.80 & -11.70 & 0.43 \\
$\theta_{v}-T_{s}$ & 30 & 0.59 & -3.70 & 0.66 \\
& Combination & 0.55 & $\times 2.19$ & 0.59 \\
& 1 & -0.22 & 13.94 & 0.08 \\
& 12 & -0.04 & 6.73 & 0.16 \\
& 16 & -0.17 & 18.30 & 0.19 \\
& 30 & -0.19 & 16.23 & 0.47 \\
& Combination & -0.06 & 10.39 & 0.02 \\
\hline
\end{tabular}

strong, and approximately linear, due to the effects of moisture on soil thermal inertia (Lakshmi et al. 2003). Nevertheless, site-specific properties can control the $T_{s}$ $-\theta_{v}$ functional form, with site clustering indicating that landscape attributes (e.g., soils, elevation, vegetation) can be useful for predicting conditions.

\section{d. Basin-averaged temporal variability of land-atmosphere interactions}

While remote land surface conditions potentially impact the monsoon onset (e.g., Gutzler and Preston 1997; Small 2001; Zhu et al. 2005), little is known about the role played by the internal surface properties in the region on sustaining the monsoon. Matsui et al. (2005) studied a vegetation-rainfall feedback in the NAM region, but point to the lack of a reliable dataset to properly depict land-atmosphere interactions. In this study, we utilize the transect measurements of loweratmospheric and soil conditions to assess the degree of land-atmosphere coupling and its temporal variability during the field campaign. To do so appropriately requires averaging over a domain of sufficient size while accounting for topographic variations. Figure 12 presents a hypsometric technique for obtaining basinaveraged hydrometeorological quantities. Hypsometry refers to the area-altitude distribution in a basin (e.g., Strahler 1952; Luo 1998). A small watershed ( 100 $\mathrm{km}^{2}$ ) draining to the Río San Miguel is derived from a 90-m DEM and divided into five elevation regions, representing landforms in the basin (mountain, slope, footslope/hill, valley, and lower valley). Note that most of the transect sites fall within the basin. Transect sites outside the basin were assumed to be valid representations of similar elevations in the watershed.

The hypsometric technique is based on using the projected area fraction of each elevation band as a weighting factor to compute the basin-averaged hydrometeorological quantity. Figure $12 \mathrm{~b}$ depicts the percentage of
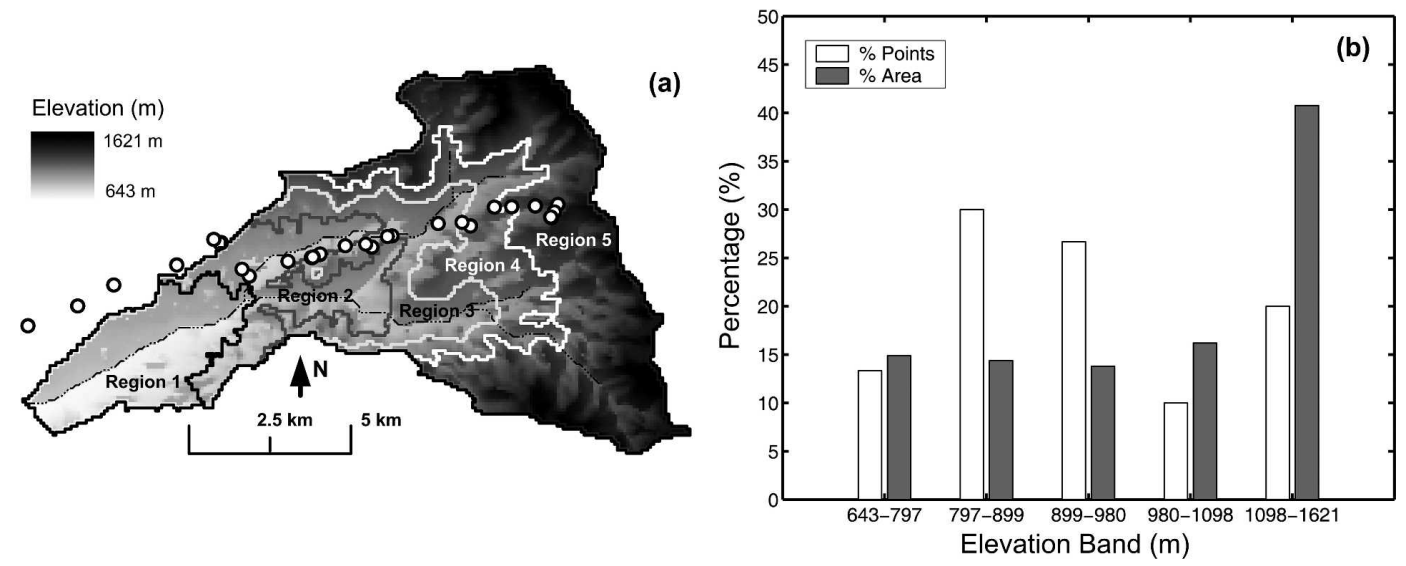

FIG. 12. Hypsometric method for averaging hydrometeorological variables over transect basin. (a) Distribution of elevation $(\mathrm{m})$ in the transect basin $\left(\sim 100 \mathrm{~km}^{2}\right)$ based on the $90-\mathrm{m}$ DEM, along with the location of the transect sites (open circles). The basin is divided into five regions or elevation bands. (b) Percentage of the basin area (\% area) and transect sites (\% points) located in the five elevation bands: region 1 (lower valley, 643-797 $\mathrm{m}$ ), region 2 (valley, 797-899 m), region 3 (footslope/hill, 899-980 m), region 4 (slope, 980-1098 m), and region 5 (mountain, 1098-1621 m). The footslope and hill landforms are grouped together as they share similar elevation ranges. The upper and lower sites in the transect correspond to $1371 \mathrm{~m}$ (site 1) and $669 \mathrm{~m}$ (site 30), respectively. 

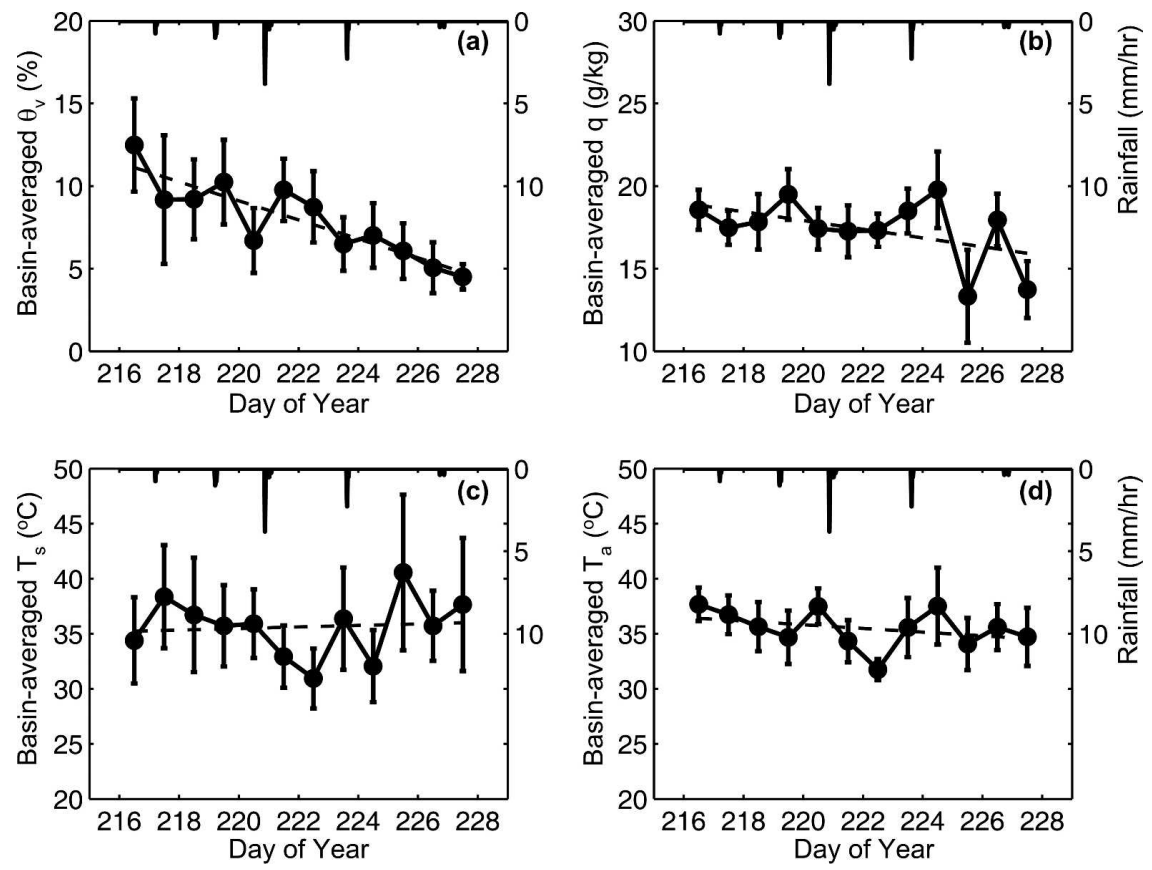

FIG. 13. Temporal variability of the basin-averaged hydrometeorological variables during the field campaign (3-14 Aug 2004; Julian days 216-227). The mean rainfall rate $\left(\mathrm{mm} \mathrm{h}^{-1}\right)$ from stations 146 and 132 along the transect is shown for reference. Shown are (a) $\theta_{v}(\%)$, (b) $q\left(\mathrm{~g} \mathrm{~kg}^{-1}\right),(\mathrm{c}) T_{s}\left({ }^{\circ} \mathrm{C}\right)$, and (d) $T_{a}\left({ }^{\circ} \mathrm{C}\right)$. Each symbol (closed circles) represents the weighted average of the regional mean values, while the vertical bars depict the weighted average of the regional std devs $( \pm 1$ std dev). For further details, refer to the description of the hypsometric averaging method. A linear regression for each hydrometeorological time series is shown as a dashed line (see Table 5).

total basin area and transect sites found in each elevation region. Note the mountain band (region 5, 1068$1621 \mathrm{~m})$ occupies the largest area fraction $(\sim 40 \%)$, but has relatively few sites $(\sim 20 \%)$ due to the difficulty in reaching high altitudes. In contrast, the valley band (region 2, 797-899 $\mathrm{m}$ ) is a small basin area percentage $(\sim 15 \%)$ and has the largest fraction of transect sites $(\sim 30 \%)$. Although a discrepancy exists between the elevation and transect site distributions, the biases introduced are minor as the soil conditions in each region are sufficiently similar (Fig. 9). Furthermore, the spatial variability in atmospheric properties is relatively small.

Figure 13 presents the temporal variability in basinaveraged land-atmosphere conditions $\left(\theta_{v}, q, T_{s}, T_{a}\right)$ along with the mean station rainfall rate during the field sampling period (days 216-227, 3-14 August). For each variable, the weighted average (symbols) and standard deviation (bars) is computed for each day using the hypsometric technique. A linear regression over the sampling period is indicated by the dashed lines (Table 5). Note the basin response to each rainfall event typically leads to an increase in $\theta_{v}$, increase in $q$, decrease in $T_{s}$ and decrease in $T_{a}$ (Figs. 13a-d). Superimposed on the event responses is an overall trend induced by hav- ing had the majority of the rainfall during July, prior to the field campaign in the basin (Fig. 7). It is evident from the temporal evolution of soil moisture that the basin is drying significantly (from $\sim 12 \%$ to $\sim 5 \%$ ). Furthermore, the spatial variability in $\theta_{v}$ decreases with time (denoted by bars), indicating that uniform dry conditions emerge by the last days. As the basin surface dries, a simultaneous decrease is observed in atmospheric moisture (from $\sim 19$ to $\sim 15 \mathrm{~g} \mathrm{~kg}^{-1}$ ), particularly for the later days. An increase in the spatial variability of $q$ is also noted as time progresses, suggesting that the atmospheric conditions are more variable as the surface becomes uniformly dry.

TABLE 5. Linear regression statistics for basin-averaged variables over the sampling period (days 216-227). The $P$ value is the significance level obtained from an $\mathrm{F}$ test applied to the linear regression.

\begin{tabular}{cccc}
\hline $\begin{array}{c}\text { Basin-averaged } \\
\text { variable }\end{array}$ & $\begin{array}{c}\text { Slope } \\
\text { (units day }^{-1} \text { ) }\end{array}$ & $R^{2}$ & $P$ value \\
\hline$\theta_{v}$ & -0.58 & 0.77 & 0.0002 \\
$\mathrm{q}$ & -0.26 & 0.23 & 0.1125 \\
$T_{s}$ & 0.07 & 0.01 & 0.7739 \\
$T_{a}$ & -0.17 & 0.12 & 0.2651 \\
\hline
\end{tabular}


The basin-averaged observations of soil moisture and specific humidity suggest that the land surface and atmosphere are coupled during this drydown period. As the mountainous terrain experiences more dramatic drying due to the lack of rainfall, it is believed that surface conditions are driving the reductions in atmospheric moisture through decreased evapotranspiration. In fact, we noted that vegetation during the later campaign days began to senesce and transpire at lower rates. Thus, the recycling of soil moisture back to the atmosphere via land surface processes is an important mechanism for sustaining high atmospheric moisture conditions (e.g., Bosilovich and Schubert 2002). Note that the basin-averaged soil and air temperatures $\left(T_{s}\right.$, $T_{a}$ ) do not exhibit significant temporal trends over the period $\left( \pm 1^{\circ} \mathrm{C}\right.$; Figs. $13 \mathrm{c}$ and $13 \mathrm{~d}$, Table 5$)$. This further indicates that the atmospheric drying trend is not related to abrupt changes in temperature conditions, but rather to diminished recycling of rainfall-induced soil moisture back to the lower atmosphere.

\section{Discussion and conclusions}

Relatively little is known about the role played by the land surface in sustaining monsoon conditions, primarily due to a serious lack of observations in the core monsoon region. As a result, a clearly identified gap in our current knowledge has been the effects of topography on precipitation processes, land-atmosphere interactions, and hydrologic response (e.g., Higgins et al. 2003; Gochis et al. 2004; Vera et al. 2006). Given the semiarid, mountainous characteristics of the NAM region, monsoon storms are a critical portion of the annual water budget and lead to significant responses at the land surface. Increases in soil moisture, for example, induce flooding in ephemeral rivers (e.g., Gochis et al. 2006) and allow the greening of a subtropical ecosystem (e.g., Salinas-Zavala et al. 2002). Therefore, an outstanding question concerns the potential for a soil moisture-vegetation-rainfall feedback mechanism to exist in the mountainous region and play a role in sustaining monsoon convection. As postulated by Eltahir (1998), increases in soil moisture and vegetation greening can affect the surface albedo and partitioning between sensible and latent heat (e.g., evapotranspiration), with subsequent effects on rainfall generation. Note that topography would significantly influence the existence of this feedback mechanism, through known effects on precipitation, air temperature, soil moisture, runoff, and vegetation distribution (e.g., Brown 1994; Descroix et al. 2002b; Coblentz and Riitters 2004; Gochis et al. 2004, 2006).

The observational data analysis and interpretations presented in this study help to address critical questions concerning land-atmosphere interactions and hydrologic response during the North American monsoon. In particular, the field experiment design was focused on assessing the topographic controls on hydrometeorological conditions through systematic daily sampling of atmospheric and soil variables over a range of elevations and ecosystem types. We identify the following characteristics of the regional hydrometeorology, soil moisture distribution, and land-atmosphere interactions in the Sierra Madre Occidental of northern Sonora, Mexico.

1) The spatial distribution of monsoon rainfall in the study region is controlled by terrain elevation and relative position along a river valley. Mountain sites receive frequent, small events, while valley sites are dominated by larger, more infrequent storms. A stronger correspondence was observed between mesoscale storms along the river valley and the basin flood response, as compared with mountain regions experiencing single-cell convection. The topographic transect was characterized by high rainfall amounts prior to the field experiment, which were comparable to regional amounts, and a general drying trend during the sampling period over most elevations.

2) The spatial and temporal patterns in soil moisture distribution indicate that elevation (and landform) helps explain much of the observed variability, in particular during wet periods. Moisture conditions after a rainfall event are quickly dissipated (following an exponential decay) through evapotranspiration, soil infiltration, or downslope lateral fluxes. As the land surface dries due to the lack of rainfall forcing, the topographic control diminishes and homogenization of soil moisture is observed across the landscape. This suggests that capturing the elevational variability of soil moisture is most critical during moist periods in the monsoon season and can affect the establishment of a soil moisture-vegetation-rainfall feedback mechanism.

3) Simultaneous atmospheric and soil conditions over a range of transect sites indicate that coupling exists (to varying degrees) between the temperature and moisture conditions across the land-atmosphere interface. Elevation and ecosystem type control the strength of the relations and lead to site clustering in the variable space. Land-atmosphere interactions reflect the ambient lapse rate and diurnal cycle of atmospheric properties and the elevation-induced variations in soil conditions. The observed coupling follows postulated trends (Eltahir 1998) that suggest 
evidence of a soil moisture-vegetation-rainfall feedback mechanism and illustrate the recycling of soil moisture (in particular for subtropical scrub) back to the atmosphere during the monsoon.

4) Basin-averaged observations of soil moisture and specific humidity were derived for each sampling day by utilizing a hypsometric technique that accounts for topographic variability over a regional domain $\left(\sim 100 \mathrm{~km}^{2}\right)$. The temporal evolution of soil moisture clearly indicates that significant drying and homogenization occurred across the transect during the sampling period. A decrease in land surface moisture ultimately began to drive reductions in atmospheric moisture through decreased recycling back to the atmosphere (evapotranspiration). The coupled drydown response at the land-atmosphere interface suggests that land surface processes in the region sustain atmospheric moisture conditions during the monsoon.

Results of this study are based on observations of atmospheric and soil surface properties obtained during a short-term field experiment within a topographic transect representing a small domain of the NAM region. Despite the limited temporal extent, the timing of the field study was fortuitously appropriate to assess the potential role of the land surface in influencing atmospheric conditions during a drydown period. Nevertheless, further work is required to conclusively verify the soil moisture-vegetation-rainfall feedback mechanism as a means for sustaining the monsoon. One appropriate avenue is to supplement existing instrument networks (e.g., Gochis et al. 2004; Gebremichael et al. 2007) with measurements of atmospheric conditions and to fill in gaps along well-selected topographic transects. Furthermore, remotely sensed observations of rainfall, water vapor, surface temperature, soil moisture, and vegetation may provide a means for assessing land-atmosphere interaction at the regional scale and the effects of vegetation changes in recycling moisture back to the atmosphere. The subtropical scrub should be targeted as it occupies broad areas of the landscape and can sustain high specific humidity despite relatively low soil moisture contents. Capturing ecosystem dynamics and terrain controls on hydrologic response is critical for properly representing the role of the land surface in numerical models of the monsoon.

Acknowledgments. We would like to acknowledge funding from the NASA Terrestrial Hydrology Program, the NASA AMSR-E Validation Program, and the NOAA North American Monsoon Experiment (NAME). We thank David Gochis (NCAR), Pamela
Nagler (USGS), and Jaime Garatuza-Payán (ITSON) for providing useful ancillary datasets for this study. We also acknowledge the excellent comments by three anonymous reviewers.

\section{REFERENCES}

Adams, D. K., and A. C. Comrie, 1997: The North American monsoon. Bull. Amer. Meteor. Soc., 78, 2197-2213.

Bosilovich, M. G., and S. D. Schubert, 2002: Water vapor tracers as diagnostics of the regional hydrologic cycle. J. Hydrometeor., 3, 149-165.

Brito-Castillo, L., A. V. Douglas, A. Leyva-Contreras, and D. Lluch-Belda, 2003: The effect of large-scale circulation on precipitation and streamflow in the Gulf of California continental watershed. Int. J. Climatol., 23, 751-768.

Brown, D. E., 1994: Biotic Communities: Southwestern United States and Northwestern Mexico. University of Utah Press, $342 \mathrm{pp}$.

Brown, D. P., and A. C. Comrie, 2002: Spatial modeling of winter precipitation in Arizona and New Mexico. Climate Res., 22, $115-128$.

CNA, 2002: Determinación de la disponibilidad de agua en el acuífero Río Sonora, Estado Sonora. Comisión Nacional del Agua, 42 pp.

CNA, 2004: Aforo de Aguas Superficiales Estación El Cajón, Río San Miguel. Subgerencia Regional del Noroeste, Comisión Nacional del Agua.

Coblentz, D. D., and K. H. Riitters, 2004: Topographic controls on the regional-scale biodiversity of the south-western USA. J. Biogeogr., 31, 1125-1138.

Cosh, M. H., T. J. Jackson, R. Bindlish, and J. H. Prueger, 2004: Watershed scale temporal and spatial stability of soil moisture and its role in validating satellite estimates. Remote Sens. Environ., 92, 427-435.

,,,--- J. S. Famiglietti, and D. Ryu, 2005: Calibration of an impedance probe for estimation of surface soil water content over large regions. J. Hydrol., 311, 49-58.

Descroix, L., J. L. Gonzalez Barrios, J. P. Vandervaere, D. Viramontes, and A. Bollery, 2002a: An experimental analysis of hydrodynamic behavior on soils and hillslopes in a subtropical mountainous environment (western Sierra Madre, Mexico). J. Hydrol., 266, 1-14.

_ J.-F. Nouvelot, and M. Vauclin, 2002b: Evaluation of antecedent precipitation index to model runoff yield in the western Sierra Madre. J. Hydrol., 263, 114-130.

Douglas, M. W., R. A. Maddox, K. Howard, and S. Reyes, 1993: The Mexican monsoon. J. Climate, 6, 1665-1677.

Eltahir, E. A. B., 1998: A soil moisture rainfall feedback mechanism 1 . Theory and observations. Water Resour. Res., 34, 765776.

Entekhabi, D., 1995: Recent advances in land-atmosphere interaction research. Rev. Geophys., 33 (S1), 995-1004.

Famiglietti, J. S., J. W. Rudnicki, and M. Rodell, 1998: Variability in surface moisture content along a hillslope transect: Rattlesnake Hill, Texas. J. Hydrol., 210, 259-281.

Gebremichael, M., E. R. Vivoni, C. J. Watts, and J. C. Rodríguez, 2007: Submesoscale spatiotemporal variability of North American monsoon rainfall over complex terrain. J. Climate, 20, 1751-1773.

Gochis, D. J., A. Jiménez, C. J. Watts, J. Garatuza-Payán, and W. J. Shuttleworth, 2004: Analysis of 2002 and 2003 warm- 
season precipitation from the North American Monsoon Experiment event rain gauge network. Mon. Wea. Rev., 132, 2938-2953.

—, L. Brito-Castillo, and W. J. Shuttleworth, 2006: Hydroclimatology of the North American monsoon region in northwest Mexico. J. Hydrol., 316, 53-70.

Gutzler, D. G., 2004: An index of interannual precipitation variability in the core of the North American monsoon region. $J$. Climate, 17, 4473-4480.

_ - and J. Preston, 1997: Evidence for a relationship between spring snow cover in North American and summer rainfall in New Mexico. Geophys. Res. Lett., 24, 2207-2210.

Higgins, R. W., and Coauthors, 2003: Progress in pan American CLIVAR research: North American monsoon system. Atmósfera, 16, 29-65.

INEGI, 1998: Modelos Digitales de Elevación 1:250, 000. Instituto Nacional de Estadística, Geografía e Informática.

INIFAP, 2001: Inventario Nacional de Suelos 1:250, 000. Instituto Nacional de Investigaciones Forestales, Agrícolas y Pecuarias.

Jackson, T. J., and A. Y. Hsu, 2001: Soil moisture and TRMM Microwave Imager relationships in the Southern Great Plains 1999 (SGP99) experiment. IEEE Trans. Geosci. Remote Sens., 39, 1632-1642.

Kurc, S. A., and E. E. Small, 2004: Dynamics of evapotranspiration in semiarid grassland and shrubland ecosystems during the summer monsoon season, central New Mexico. Water Resour. Res., 40, W09305, doi:10.1029/2004WR003068.

Lakshmi, V., T. J. Jackson, and D. Zehrfuhs, 2003: Soil moisturetemperature relationships: Results from two field experiments. Hydrol. Processes, 17, 3041-3057.

Luo, W., 1998: Hypsometric analysis with a geographic information system. Comput. Geosci., 24, 815-822.

Matsui, T., V. Lakshmi, and E. E. Small, 2005: The effects of satellite-derived vegetation cover variability on simulated land-atmosphere interactions in the NAMS. J. Climate, 18, 21-40.

NAME Project Science Team, 2004: North American Monsoon Experiment (NAME): Science and implementation plan. NOAA/NCEP/CPC, 96 pp. [Available online at http://www. cpc.ncep.noaa.gov/products/precip/monsoon/.]

Paredes-Aguilar, R., T. R. Van Devender, and R. S. Fegler, 2000: Cactáceas de Sonora, Mexico: Su Diversidad, Uso y Conservación. Arizona-Sonora Desert Museum Press, 132 pp.

Rodríguez-Iturbe, I., 2000: Ecohydrology: A hydrologic perspective on climate-soil-vegetation dynamics. Water Resour. Res., 36, 3-9.

Rogers, R. R., and M. K. Yau, 1989: A Short Course on Cloud Physics. 3d ed. Butterworth-Heinemann, 304 pp.

Salinas-Zavala, C. A., A. V. Douglas, and H. F. Díaz, 2002: Inter- annual variability of NDVI in northwest Mexico: Associated climatic mechanisms and ecological implications. Remote Sens. Environ., 82, 417-430.

Schmugge, T., T. J. Jackson, W. P. Kustas, R. Roberts, R. Parry, D. C. Goodrich, S. A. Amer, and M. A. Weltz, 1994: Push broom microwave radiometer observations of surface soil moisture in Monsoon '90. Water Resour. Res., 30, 1321-1328.

Seyfried, M. S., and M. D. Murdock, 2004: Measurement of soil water content with a $50-\mathrm{MHz}$ soil dielectric sensor. Soil Sci. Soc. Amer. J., 68, 394-403.

Sheppard, P. R., A. C. Comrie, G. D. Packin, K. Angersbach, and M. K. Hughes, 2002: The climate of the US southwest. Climate Res., 21, 219-238.

SIUE-IMADES, 1998: Proyecto de Ordenamiento Ecológico del Territorio del Estado de Sonora. Instituto del Medio Ambiente y Desarrollo Sustentable del Estado de Sonora, 577 pp.

Small, E. E., 2001: The influence of soil moisture anomalies on variability of the North American monsoon system. Geophys. Res. Lett., 28, 139-142.

—_, and S. A. Kurc, 2003: Tight coupling between soil moisture and the surface radiation budget in semiarid environments: Implications for land-atmosphere interactions. Water Resour. Res., 39, 1278, doi:10.1029/2002WR001297.

SMEX Science Team, 2004: Soil Moisture Experiments in 2004 Experiment plan. USDA, $132 \mathrm{pp}$. [Available online at http:// hydrolab.arsusda.gov/smex04/.]

SPP, 1984: Carta Geológica 1:250, 000 H12-5. 1st ed. Dirección General de Geografía, México, Secretaría de Programación y Presupuesto.

Strahler, A. N., 1952: Hypsometric (area-altitude) analysis of erosional topography. Bull. Geol. Soc. Amer., 63, 1117-1142.

Vera, C., and Coauthors, 2006: A unified view of the American monsoon systems. J. Climate, 19, 4977-5000.

Xie, P., Y. Yarosh, M. Chen, R. Joyce, J. E. Janowiak, and P. A. Arkin, 2005: Diurnal cycle of cloud and precipitation associated with the North American monsoon system: Preliminary results for 2003 and 2004. Preprints, 16th Conf. on Climate Variability and Change, San Diego, CA, Amer. Meteor. Soc., CD-ROM, 4.22

Xu, J. J., X. Gao, J. Shuttleworth, S. Sorooshian, and E. Small, 2004a: Model climatology of the North American monsoon onset period during 1980-2001. J. Climate, 17, 3892-3906.

, W. J. Shuttleworth, X. Gao, S. Sorooshian, and E. E. Small, 2004b: Soil moisture-precipitation feedback on the North American monsoon system in the MM5-OSU model. Quart. J. Roy. Meteor. Soc., 130, 2873-2890.

Zhu, C., D. P. Lettenmaier, and T. Cavazos, 2005: Role of antecedent land surface conditions on North American monsoon rainfall variability. J. Climate, 18, 3104-3121. 